\title{
Acceptable Knowledge Summary Report for Mixed TRU Waste Streams: SR-W026-221F-HET-A through D
}

by

G. F. Lunsford

Westinghouse Savannah River Company

Savannah River Site

Aiken, South Carolina 29808

This paper was prepared in connection with work done under the above contract number with the U. S. Department of Energy. By acceptance of this paper, the publisher and/or recipient acknowledges the U. S. Government's right to retain a nonexclusive, royalty-free license in and to any copyright covering this paper, along with the right to reproduce and to authorize others to reproduce all or part of the copyrighted paper. 
This document was prepared in conjunction with work accomplished under Contract No. DE-AC09-96SR18500 with the U.S. Department of Energy

\section{DISCLAIMER}

This report was prepared as an account of work sponsored by an agency of the United States Government. Neither the United States Government nor any agency thereof, nor any of their employees, makes any warranty, express or implied, or assumes any legal liability or responsibility for the accuracy, completeness, or usefulness of any information, apparatus, product or process disclosed, or represents that its use would not infringe privately owned rights. Reference herein to any specific commercial product, process or service by trade name, trademark, manufacturer, or otherwise does not necessarily constitute or imply its endorsement, recommendation, or favoring by the United States Government or any agency thereof. The views and opinions of authors expressed herein do not necessarily state or reflect those of the United States Government or any agency thereof.

This report has been reproduced directly from the best available copy.

Available for sale to the public, in paper, from U.S. Department of Commerce, National Technical Information Service, 5285 Port Royal Road, Springfield, VA 22161

phone: (800) 553-6847

fax: (703) 605-6900

email: orders@ntis.fedworld.gov

online ordering: http://www.ntis.gov/support/index.html

Available electronically at http://www.doe.gov/bridge

Available for processing fee to U.S. Department of Energy and its contractors, in paper, from: U.S. Department of Energy, Office of Scientific and Technical Information, P.O. Box 62, Oak Ridge, TN 37831-0062, phone: (865) 576-8401, fax: (865) 576-5728, email: reports@adonis.osti.gov 


\section{Savannah River Site Waste Isolation Pilot Plant Disposal Program}

\section{Acceptable Knowledge Summary Report for Mixed TRU Waste Streams: SR-W026-221F-HET-A through D}

Date: September 25, 2001

Revision 0

Prepared by:
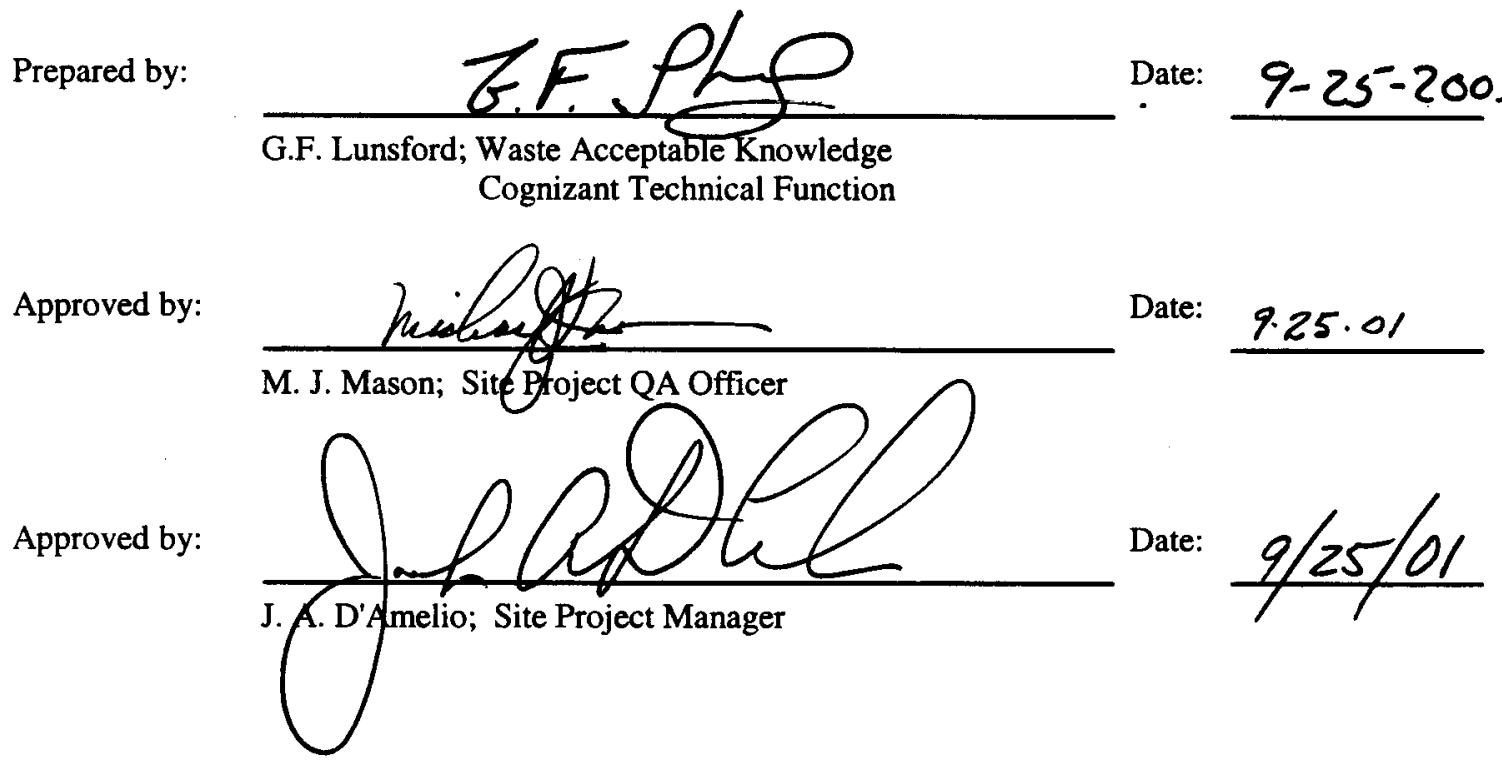

Date: $9-25-2001$

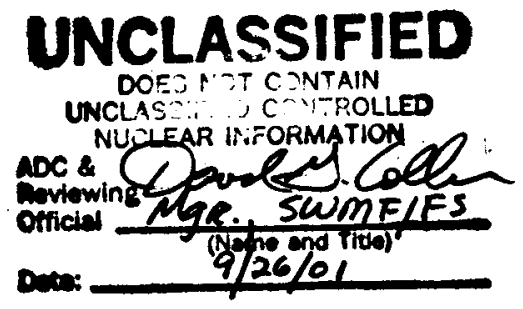




\section{TABLE OF CONTENTS}

\section{Page Number}

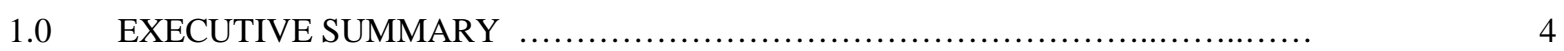

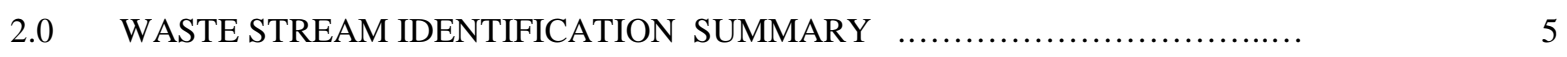

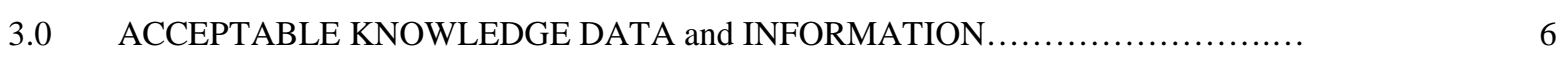

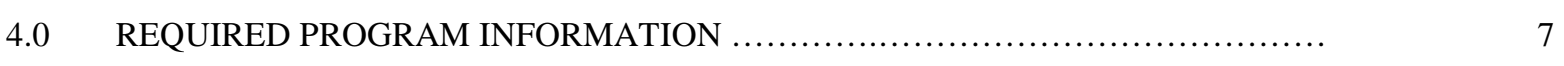

4.1 Facility Location, Description and Mission ….............................

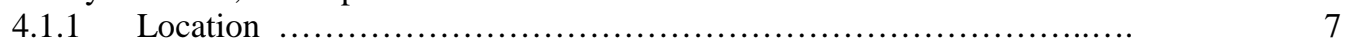

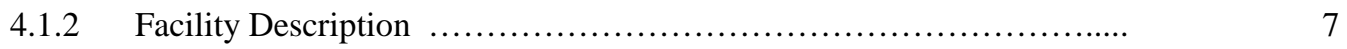

4.1.3 Process Equipment Description .................................. 8

4.1.4 Mission .................................................................

4.2 Description of Process From Which Waste Was Generated ...................... 11

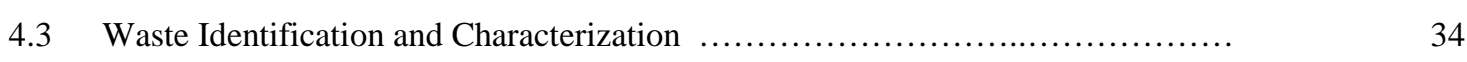

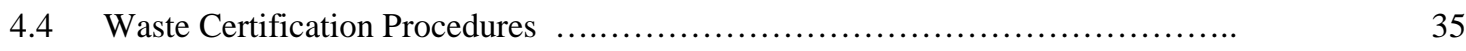

5.0 REQUIRED WASTE STREAM INFORMATION .................................

5.1 Area and Building From Which Waste Was Generated ......................... 36

5.2 Waste Stream Volume and Period of Generation ................................

Correlation of Waste Streams Generated from the same
Building and Process $\ldots \ldots \ldots \ldots \ldots \ldots \ldots \ldots \ldots \ldots \ldots \ldots \ldots \ldots \ldots \ldots \ldots \ldots \ldots \ldots \ldots \ldots \ldots \ldots \ldots \ldots \ldots \ldots \ldots \ldots \ldots \ldots \ldots$

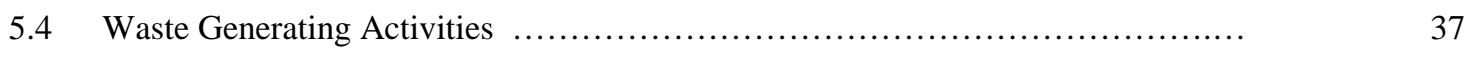

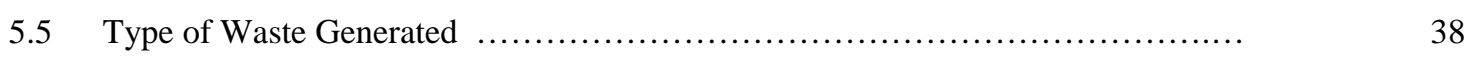

5.5.1 Material Inputs Related to Physical Form, Chemical and

Radiological Waste Characteristics ................................... 39

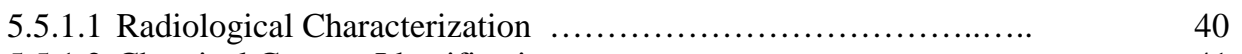

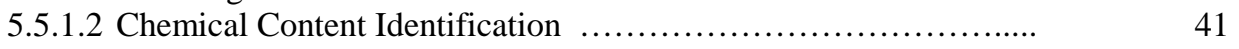

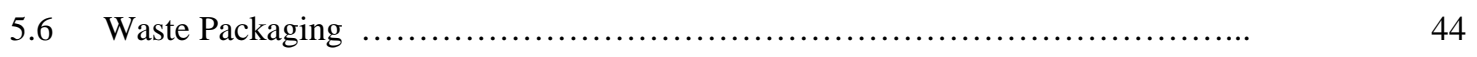

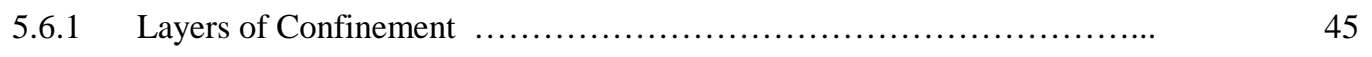

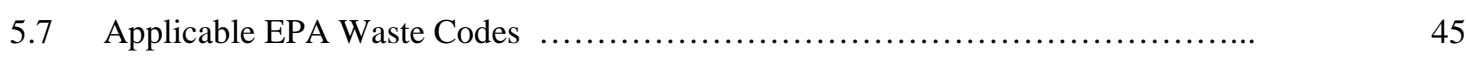

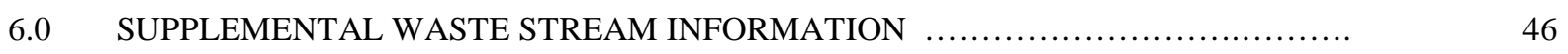

6.1 Container Examination and Evaluation Program .............................. 46

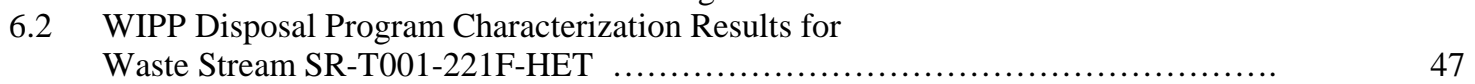




\section{TABLE OF CONTENTS (Continued)}

\section{Page Number}

7.0 CONTAINER SPECIFIC INFORMATION

8.0 ATTACHMENTS

8.1 MAPS .

49

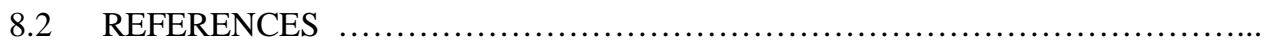

8.3 GLOSSARY 


\subsection{EXECUTIVE SUMMARY}

Since beginning operations in 1954, the Department of Energy's Savannah River Site FB-Line conducted atomic energy defense activities consistent with the listing in Section 10101(3) of the Nuclear Waste Policy Act of 1982. Specifically, the FB-Line was a defense nuclear materials production facility. The facility mission was to process and convert dilute plutonium solution into highly purified weapons grade plutonium metal. As a result of various activities conducted in support of the mission (e.g., operation, maintenance, repair, clean up, and facility modifications), the facility generated transuranic waste.

This document, along with referenced supporting documents provides a defensible and auditable record of acceptable knowledge for the heterogeneous debris mixed transuranic waste streams generated in the FB-Line after January 25, 1990 and before March 20, 1997. The waste was packaged in 55-gallon drums, then shipped to the transuranic waste storage facility in "E" area of the Savannah River Site.

This acceptable knowledge report includes information relating to the facility's history, configuration, equipment, process operations and waste management practices. Information contained in this report was obtained from numerous sources including: facility safety basis documentation, historical document archives, generator and storage facility waste records and documents, and interviews with cognizant personnel. All referenced documentation is maintained in files located in the WIPP Records Facility located in Building 642-E at the Savannah River Site.

This report is fully responsive to the requirements of Section B4 "Acceptable Knowledge" from the Hazardous Waste Facility Permit Issued to Waste Isolation Pilot Plant, EPA No. NM4890139088 ${ }^{2}$, and provides a sound (and auditable) characterization that satisfies WIPP criteria for Acceptable Knowledge. 


\subsection{WASTE STREAM IDENTIFICATION SUMMARY}

\section{Waste Stream Identification Numbers:}

SR-W026-221F-HET-A: This stream is assigned hazardous waste number D008 for lead material. SR-W026-221F-HET-B: This stream is assigned hazardous waste number D007 for chromium. SR-W026-221F-HET-C: This stream is assigned hazardous waste number D009 for mercury. SR-W026-221F-HET-D: This stream is assigned hazardous waste number D006 and D008 for cadmium and lead.

Site Where TRU Waste Was Generated: $\quad$ Savannah River Site, Post Office Box 616, Aiken, South Carolina, 29802

Facility Where TRU Waste Was Generated: 221-F, FB-Line

Facility Mission: The 221-F, FB-Line was a defense nuclear material production facility where dilute plutonium solutions were concentrated and purified into plutonium metal for weapons use.

Waste Stream Description: These waste streams are contact-handled mixed transuranic waste resulting from glove box operations, decontamination, housekeeping, maintenance and construction activities. The waste is heterogeneous and consists mainly of dry organic debris such as personnel protective equipment (i.e., shoe covers, lab coats, plastic suits), floor sweepings, rags, lab ware, plastics, wood, paper and other incidental job control type waste. The waste also includes inorganic debris consisting of metal components (i.e., hand tools, small equipment), glass and absorbent materials. Hazardous materials in these waste streams include lead, chromium, cadmium and mercury. Mercury present in waste stream SR-W026-221F-HET-C is not in liquid form. Waste from this stream is contaminated primarily with weapons grade plutonium consisting of the following radioisotopes: ${ }^{238} \mathrm{Pu},{ }^{239} \mathrm{Pu}$, ${ }^{240} \mathrm{Pu},{ }^{241} \mathrm{Pu},{ }^{242} \mathrm{Pu}$. Americium - 241 is present as a result of in-growth from beta decay of ${ }^{241} \mathrm{Pu}$. Other radionuclides may be present in trace quantities. Further discussion of the physical, radiological and chemical characteristics of this waste is described in Section 5.5.1.

Summary Category Group:

Waste Matrix Code Group:

Waste Matrix Code:
S5000 - Debris Waste

Heterogeneous

S5440 - Predominantly Organic Debris

TRUPACT-II Content Code (TRUCON): SR225 F 


\subsection{ACCEPTABLE KNOWLEDGE DATA and INFORMATION}

Transuranic waste destined for disposal at the Waste Isolation Pilot Plant must be characterized prior to shipment. The WIPP Hazardous Waste Permit Waste Analysis Plan ${ }^{2}$ permits use of knowledge of the materials and processes that generate and control the waste provided a clear and convincing argument about the characteristics of the waste is achieved. This acceptable knowledge characterization is fully responsive to the requirements of the WIPP Waste Analysis Plan and was achieved as outlined in Section B4 of the Savannah River Site WIPP Disposal Program Quality Assurance Project Plan $^{3}$ and implemented via the Solid Waste Division "Acceptable Knowledge" procedure $^{4}$.

These waste streams were characterized using acceptable knowledge stemming from a variety of sources. Primarily, controlled FB-Line facility documentation effective during the period of waste generation was used as the basis for this characterization. Examples include facility specific Authorization Basis documents, facilityoperating procedures, waste package data sheets, and completed burial ground records. Specific revisions of controlling documentation in effect during generation and processing of waste from this stream were obtained and used. All documentation used to derive this report is denoted throughout by superscript numerals (e.g., ${ }^{69}$ ) which correlate to the Reference Listing shown in Attachment 2. Each reference is maintained in the WIPP Records Facility located in building 642-E at the Savannah River Site. 


\subsection{REQUIRED PROGRAM INFORMATION}

\subsection{Facility Location, Description and Mission}

\subsubsection{LOCATION: $:^{6,7,8,9,10}$}

The Savannah River Site is located in South Carolina on approximately 310 square miles. It is bounded on the southwest by the Savannah River and occupies parts of Aiken, Barnwell and Allendale counties. The FB-Line facility is located inside the 221-F Canyon building in the 200-F Separations Area of the Savannah River Site. Maps $^{5}$ denoting the location of the Site, the 200-F Separations Area within the site boundary, the waste generating facility within F-Area and the transuranic waste storage areas are included as Attachment 1.

\subsubsection{FACILITY DESCRIPTION:}

The original facility was constructed in 1951-1953 and later upgraded during 1957-1958. The 221-F Canyon building, which houses the FB-Line facility, is a large reinforced concrete structure approximately 850 feet long, 122 feet wide and 66 feet tall. The FB-Line is located in Sections one through five and the third through sixth levels of the canyon building. Processing equipment in the facility is enclosed in either cabinets or glove boxes to minimize the spread of radiological contamination. The enclosures are constructed of stainless steel with welded joints (some older enclosures use gasketed joints). To further aid with efforts to prevent the spread of contamination, the FB-Line is designed to provide an operating side and a maintenance side. Major pieces of equipment are located near the maintenance side of the process enclosure. In some cases, equipment is located inside of enclosures called "wing cabinets" which protrude into the maintenance room. Any breach of radiological containment for maintenance is conducted from the maintenance side of the line. When such a breach is necessary, a temporary enclosure (hut) is made of sheet plastic material to surround the cabinet or glove box panel to be removed. The hut permits ingress / egress to the process enclosure while still confining radiological contamination. Airflow patterns are cascaded to direct flow from non-contaminated areas of the facility to those progressively more contaminated. That is, from personnel corridors to operations areas to maintenance rooms to process enclosures (cabinets / glove boxes), then eventually through the facilities filtered exhaust system. 


\subsubsection{PROCESS EQUIPMENT DESCRIPTION ${ }^{100}$ :}

Primary operating equipment within the FB-Line is designed and fabricated of corrosion resistant material depending on the operation and corrosive(s) being contacted. Most materials of construction are Type 304L stainless steel. Plastics, precious metals and special alloys such as Hastelloy ${ }^{\circledR \square}$ and Inconel ${ }^{\circledR}$ are used in locations where warranted by service conditions. A description of individual pieces of major process equipment is presented below.

\section{Cation Exchange Vessels}

The primary cation exchange equipment consists of 14 tanks, 4 ion exchange columns and 4 filters. Each vessel is constructed of Type 304L stainless steel. The tanks range in capacity from 30 liters up to 2500 liters.

\section{Cation Exchange Columns}

The four cation exchange columns each consist of two cylindrical segments connected in series. Each segment is approximately ten inches in diameter with resin bed five inches high. A neutron-absorbing shield is located between the two segments of each column and on top of each segment. The shield is fabricated of thin sheets of cadmium in a polyethylene envelope. Each segment is also shielded with two-inch thick lead.

\section{Precipitation and Filtration}

Precipitation and filtration is accomplished using four precipitator systems. Each system is housed in a separate wet-chemical glove box that contains a two-stage precipitator and a filtration run tank.

Precipitation Equipment: Each first stage precipitator is cylindrical in design. Two of the precipitators are constructed of polyethylene and two of $\operatorname{Kynar}^{\circledR}$ (a polyvinylidene fluoride material). Each precipitator is held to specified dimensions by metal supports fabricated from Hastelloy ${ }^{\circledR}$ C. Inlet and outlet tubing is a trade name plastic material called SYGEF ${ }^{\circledR}$. Second stage precipitators are slab designs fabricated from polyethylene and Kynar $^{\circledR}$ materials (2 each respectively). Dimensional shape for these precipitators is also secured using Hastelloy ${ }^{\circledR} \mathrm{C}$ support structures. 
Filtration Equipment: Plutonium product solution is drawn by vacuum from the second stage precipitator through a filter boat where the plutonium product material is captured on filter media. Filter boats are cylindrical in shape and fabricated from $304 \mathrm{~L}$ stainless steel with a platinum liner. Filter media is made from Kynar ${ }^{\circledR}$ material. The filtration head and piping are constructed of either polyvinyl chloride or Kynar ${ }^{\circledR}$ materials. Outlet tubing is Nylobraid ${ }^{\circledR \square}$ material. The filter station sump is fabricated using 304L stainless steel lined with Hypalon ${ }^{\circledR}$

\section{Drying and Conversion (Roasting)}

Drying Station: Plutonium product (in the form of filter cake) contained in a filter boat is transferred to one of four drying stations where warm, dry air is drawn through the cake. Each drying station is fabricated using Hastelloy ${ }^{\circledR} \mathrm{C}$ material.

Conversion (Roasting) Station: After drying, plutonium product is dumped from the filter boat into a roasting pan. Roasting pans are cylindrical, open topped vessels constructed of Hastelloy ${ }^{\circledR} \mathrm{C}$. The roasting pan is then transferred to one of four roasting furnaces. Each furnace is heated by three, 5000 -watt Calrod ${ }^{\circledR \square}$ heaters.

\section{$\underline{\text { Reduction and Finishing }}$}

In the reduction step, a roasted mixture of plutonium tetra fluoride and plutonium oxide is dumped from the roasting pan into a mixing container. The material is weighed, calcium metal is added and materials are mixed in a mixer-dumper. The mixture is then dumped into a pressure chamber containing a magnesium oxide crucible nested in magnesium oxide sand. The crucible is covered with a stainless steel lid and the reduction vessel is sealed and placed in one of two reduction furnaces. After reduction and cooling, the regulus is dumped from the reduction vessel, marked for identification, pickled, drilled to obtain an analytical sample, weighed and packaged for storage. All of these operations are conducted in glove boxes that make up the Mechanical Line. 
Dumping Stations: Three dumping stations are used in the Mechanical Line to dump intermediate powders from one container to another:

- "Boat Dumper" dumps from the filter boat to the roasting pan.

- "Pan Dumper" dumps from the roasting pan to the mix and weigh station.

- "Mixer-Dumper" mixes the reaction charge in the mix and weigh vessel.

The boat dumper and pan dumpers are similar. The mixer-dumper is essentially the same as the other two except that it is equipped with a chain-drive system for rotating the equipment to mix the reduction charge. Each dumper has a set of latches to engage the boat or pan and hold it to the frame. Additionally, each has a funnel with a drop valve assembly, a vibrator and a hand wheel for rotating the dumper.

Weighing Station: A weigh station is located in the roasting pan dumping glove box. The device uses a pressure sensitive transducer sandwiched in the head of a hydraulic lift. The hydraulic lift raises the load cell to support the weighing vessel.

Reduction Vessel (Pressure Chamber): The pressure chamber is cylindrical in shape and is fabricated of Type 316 stainless steel. The chamber is sized to receive a magnesium oxide crucible. After placement of a crucible in the chamber, the crucible is covered with a stainless steel lid fabricated with Type 304L stainless steel. The pressure chamber seals to the reduction furnace with a copper gasket. A stainless steel diaphragm is attached to the gasket to protect the furnace head during firing.

Reduction Furnace: There are two reduction furnaces in the Mechanical Line that heat the charge contained in the reduction vessel. The furnace heating units are water-cooled induction coils with power supplied by a common 30$\mathrm{Kw}, 10-\mathrm{KHz}$ motor generator set. Induction coils are fabricated from copper. The reduction vessel is placed inside an induction coil and is sealed against the furnace head by a hydraulic lift. The lift system is powered with high-pressure nitrogen. During the operation, the reduction vessel is pressurized with argon. The furnace head is constructed of Hastelloy ${ }^{\circledR} \mathrm{C}$. 


\subsubsection{MISSION: ${ }^{6,7,8,9,10}$}

Since beginning operations in 1954, the FB-Line mission was production of Weapons Grade Plutonium used in assembly of atomic weapons. This mission meets all criteria as an atomic energy defense activity (i.e., defense nuclear materials production) as listed in section 10101(3) of the Nuclear Waste Policy Act of $1982^{94}$. The facility had two functions: 1) to convert dilute plutonium solution received from the 221-F Canyon into highly purified $\mathrm{Pu}$ metal; and 2) to recover weapons grade plutonium from scrap materials produced while operating FB-Line and from scrap material shipped to the SRS from other off-site facilities. Process operations were discontinued in January 1990 for routine maintenance and project upgrades. During the shutdown, a program was initiated to inspect exhaust ducts and clean them of any plutonium accumulation. Process operations were not restarted until November 1995 when the facility's mission became the processing of existing inventories of plutonium and plutonium containing materials to achieve a stable form suitable for long term storage.

\subsection{Description of Process From Which Waste Was Generated $6,7,8,9,10$}

\section{Primary Processes}

Plutonium isotopes were separated from uranium, fission products (primarily ${ }^{137} \mathrm{Cs},{ }^{90} \mathrm{Sr},{ }^{95} \mathrm{Zr},{ }^{95} \mathrm{Nb},{ }^{103} \mathrm{Ru}$ and ${ }^{106} \mathrm{Ru}$ ) and chemical impurities (primarily $\mathrm{Fe}^{+3}, \mathrm{Al}^{+3}, \mathrm{Na}^{+}, \mathrm{So}_{4}{ }^{-2}$ and sometimes $\mathrm{F}^{-}$) in the 221-F canyon processes. Purified plutonium isotopes contained in a dilute nitric acid and hydroxylamine nitrate solution were transferred to the FB-Line where it was processed to either plutonium metal or plutonium oxide form. Underlying principles of FB-Line finishing processes are explained in terms of extractive metallurgy. The initial unit operations; concentration of plutonium nitrate by cation exchange, precipitation of plutonium as a trifluoride, filtration and washing are best described as hydrometallurgical operations. The remaining unit operations; warm air drying, oxidation by roasting in an oxygen atmosphere and reduction with calcium metal to purified plutonium metal form are pyrometallurgical operations. 
Figure 1. - General FB-Line Process Flow Diagram shows the general process flow diagram for FB-Line facility operations. The operations are divided into the seven process steps listed below. A separate detailed discussion for each step follows in the respective sections indicated below.

\subsubsection{Cation Exchange \\ 4.2.2 Precipitation and Filtration \\ 4.2.3 Drying and Conversion (Roasting) \\ 4.2.4 Reduction \\ 4.2.5 Plutonium Metal Finishing \\ 4.2.6 Recovery \\ 4.2.7 Special Recovery}

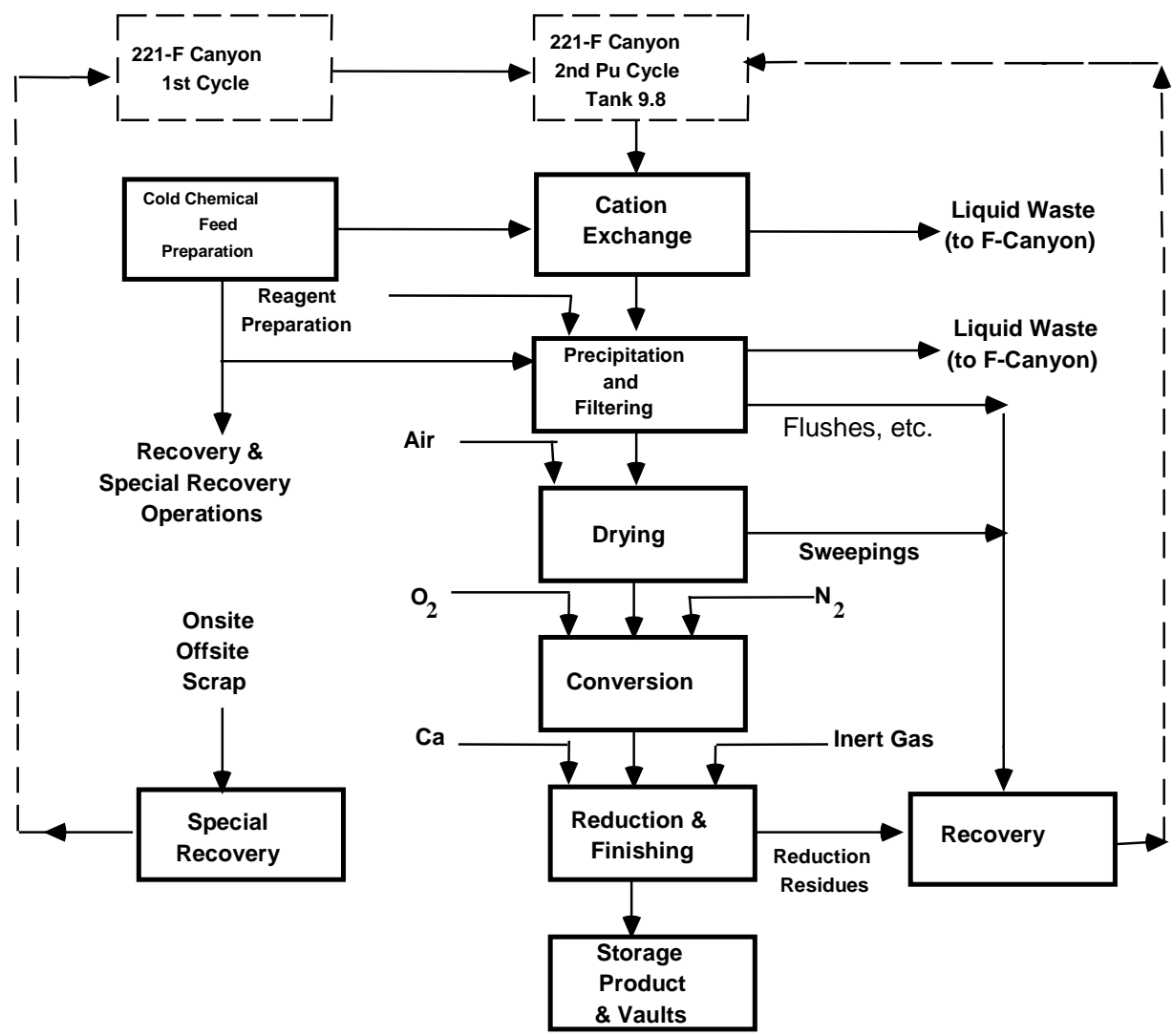

Figure 1. - General FB-Line Process Flow Diagram

NOTE: Dashed lines indicate processing outside the FB-Line 


\subsubsection{Cation Exchange}

The purpose of cation exchange (coupling) is to concentrate plutonium product solution (2BP) from the warm canyon second plutonium solvent extraction cycle (See Figure 2 - Cation Exchange Flow Diagram). The solution is transferred by steam jet from the canyon storage tank (9.8) to the feed receipt tanks $(\mathrm{C}-1 \mathrm{~A}$ or $\mathrm{C}-1 \mathrm{~B})$ on the fourth level of the FB-Line facility. Before receiving the solution, the FB-Line operator verifies that analytical results for the canyon tank 9.8 are within the specified chemical and isotopic composition range and that the plutonium concentration is less than an established value. Solutions containing greater than the established plutonium concentration may be processed by special procedure.

Plutonium valence adjustment is not required prior to loading on the cation exchange column because it is received from the canyon in the required oxidation state $(+3)$. Dilute hydroxylamine nitrate in the solution as received from the canyon prevents oxidation of the plutonium to higher valence states.

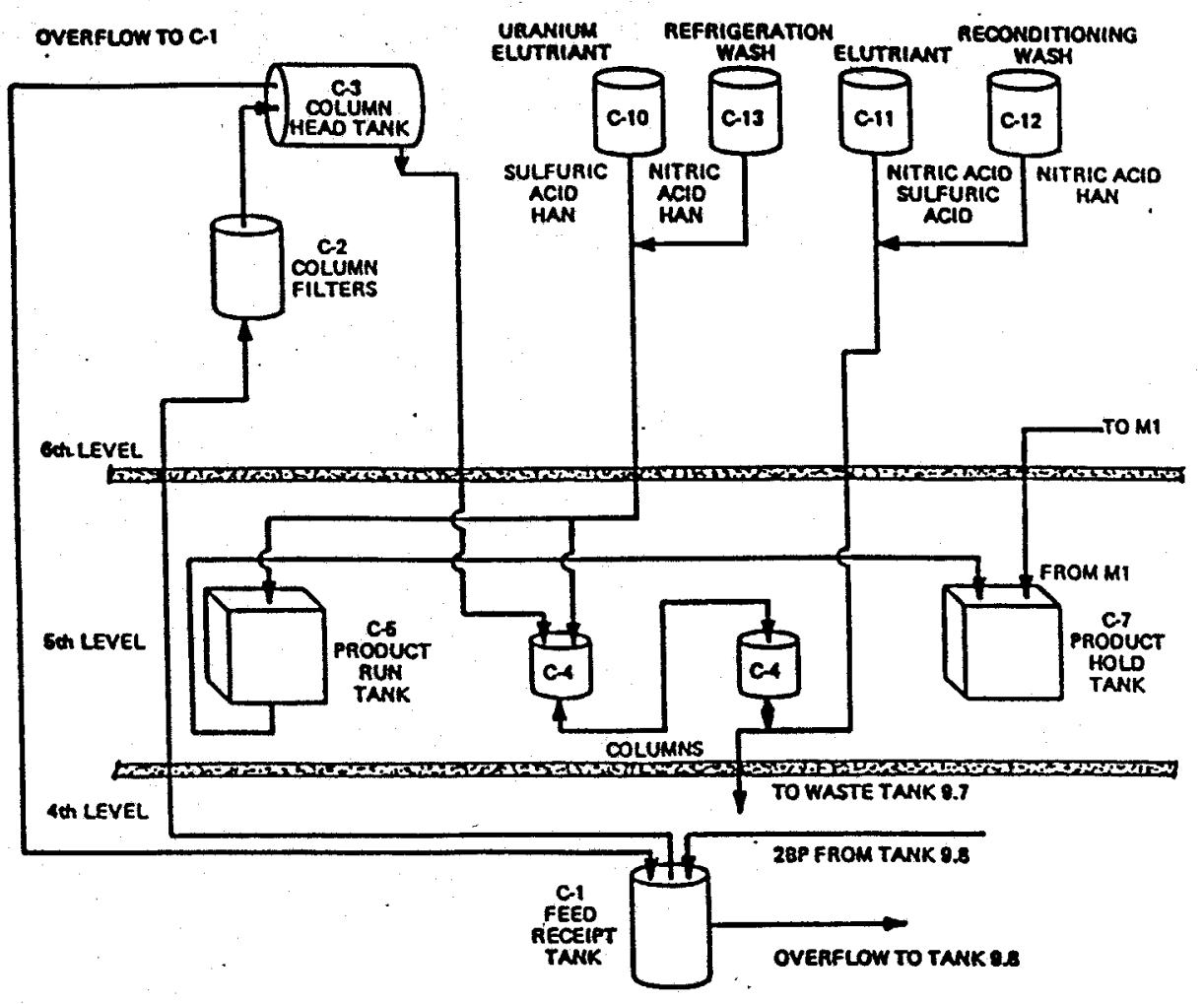

Figure 2. - Cation Exchange Flow Diagram 
Process experience has shown that when 2BP is stored for long periods, additional reductant is needed to maintain the trivalent oxidation state. The preferred reductant is hydroxylamine nitrate. The operation of cation exchange with plutonium in the trivalent state is desired for several reasons:

- The resin has greater capacity for plus three plutonium than for plus four plutonium.

- The plus three plutonium desorbs from the resin in strong nitric acid more readily than plus four plutonium.

- The plus four plutonium complexes with sulfate ion and is stripped from the resin by sulfuric acid washes used for uranium and fission product decontamination.

For various reasons, e.g., equipment malfunctions, maintenance outages, isotopic blending, etc. it is sometimes necessary to store $2 \mathrm{BP}$ solution before proceeding with the finishing operations in the FB-Line. Frequently, after a short storage period, dark brown dense solids have appeared in FB-Line rotameters, filters, and tanks. The presence of these solids is undesirable because they contribute to the plugging of rotameters, valves, filters, and process piping.

Laboratory tests determined that the solids form in 2BP solutions that are saturated with tributylphosphate (TBP). As initially precipitated, the solids are white or cream in color and float on the surface of the 2BP solution. Upon aging, and some mixing, and more precipitation, the solids turn tan to dark brown in color and form clumps. The solids were shown to be a mixture of plutonium (III) and plutonium (IV) dibutylphosphate (DBP) compounds.

The DBP is formed by radiolytic decomposition of TBP. Removal of aqueous soluble TBP by diluent washing prevents solids from forming in $2 \mathrm{BP}$ solutions. The diluent washing operation is performed using n-paraffin hydrocarbon in F-Canyon tank 9.5. As each batch of fresh 2BP is added to tank 9.5 from the second plutonium cycle, the two phases are agitated to extract TBP from the aqueous $2 \mathrm{BP}$ into the n-paraffin diluent. After approximately six weeks of diluent washing or when the TBP concentration in the n-paraffin hydrocarbon approaches an established value, the spent diluent is transferred to solvent cleanup and eventually is used for solvent makeup. The washed $2 \mathrm{BP}$ solutions can now be stored without solids forming and/or transferred to FBLine for additional processing.

After cooling, a plutonium feed batch is pumped from the feed receipt tank (C-1A or C-1B tank located on the fourth level) to column feed head tank (C-3A or C-3B tank located on the sixth level). During the transfer, the solution is filtered through filter numbers (C-2A, B, C, or D). 
A feed batch of plutonium solution is allowed to flow by gravity to the cation exchange column C-4A ( or C-4B, or C-4C or C-4D) on the fifth level. Each column is physically divided into two segments. Cations of plus three charge and higher $\left(\mathrm{Pu}^{+3}, \mathrm{Al}^{+3}, \mathrm{Am}^{+3}\right.$, etc.) are absorbed on Dowex ${ }^{\circledR}$. (Dow Chemical Co., Midland, MI) 50W-X12 (40 to 50 mesh) cation resin.

Cationic impurities of +2 charge and lower $\left(\mathrm{Fe}+{ }^{2}, \mathrm{UO}_{2}{ }^{+2}, \mathrm{ZrO}_{2}{ }^{+2}, \mathrm{NbO}_{2}{ }^{+2}, \mathrm{RuO}_{2}{ }^{+2}\right)$ are partially displaced by the plutonium (+3), thus causing a portion of them to pass through the cation exchange columns. If additional purification is required, cationic impurities are eluted from the columns by passing a dilute sulfuric acidhydroxylamine nitrate solution from tank C-10 downward through the columns to tank 9.7. The sulfuric acid forms sulfate anion complexes with the cationic impurities thus allowing them to be removed. Residual sulfuric acid is displaced by a dilute nitric acid-hydroxylamine nitrate solution.

Plutonium is eluted from each column (fifth level) by an upward flow of strong nitric acid and sulfamic acid (stabilizer) gravity fed from a dedicated cold feed tank C-11 (sixth level). This is followed by a weak acid reconditioning wash from the $\mathrm{C}-12$ tank (sixth level) through the cation exchange columns to the product run tank C-5 (fifth level). Nitric acid concentration is controlled to provide efficient elution and avoid uncontrolled oxidation of the plutonium from the plus three to the plus four oxidation state. The eluted plutonium solution is transferred to the product hold tank C-7 (fifth level) for sampling and analysis. After analysis, the plutonium is transferred to the concentrate feed tank M-1 (sixth level) for subsequent precipitation.

The resin may contain gases $\left(\mathrm{NO}_{\mathrm{x}}\right)$ generated by nitric acid decomposition. These gases normally escape through the process vent system. Sometimes it is necessary to remove the gasses by passing a refrigerated solution of dilute nitric acid and hydroxylamine nitrate down through the column from the cold feed tank C-13 (sixth level) to the canyon tank 9.7. After product elution, the resin is prepared for the next sorption cycle with a weak (dilute) reconditioning solution of nitric acid and hydroxylamine nitrate.

\subsubsection{Precipitation and Filtration}

Precipitation and filtration are the unit operations that bridge the gap between hydrometallurgical and pyrometallurgical operations. Whereas, the prior unit operations can have an affect on the purity of the final product, all unit operations from precipitation to product metal can effect the purity and yield of the metal product. Precipitation and filtration (See Figure 3 - Precipitation and Filtration Flow Diagram) produce plutonium trifluoride cake from the plutonium solution eluted from the cation exchange columns. First, the plutonium is treated with sulfamic and ascorbic acids to reduce any plus four valence plutonium to the plus three valence required for satisfactory precipitation. 
The presence of the plus four valence plutonium leads to high filtrate losses that may require recycle of the filtrate. This is because plutonium tetrafluoride has a higher solubility than plutonium trifluoride. In addition, the +4 valence plutonium fluoride precipitate has undesirable physical properties. That is, the plutonium tetrafluoride crystals are much finer and harder to filter.

Precipitation of plutonium (IV) from aqueous solutions gives the hydrate, $\mathrm{PuF}_{4} \cdot 2.5 \mathrm{H}_{2} \mathrm{O}$ which also effects downstream operations. For instance, the hydrate trends to form "rocks" which are sufficiently large to plug process lines. The hydrate also does not dry well. Dehydration of the hydrate results in reduction of the tetrafluoride to trifluoride. This loss of fluoride reduces the heat of reduction which effects the energy balance necessary for separation of the molten plutonium metal from the molten slag in the reduction step (see Section 4.5 for details).

Plutonium trifluoride is precipitated by simultaneously adding hydrofluoric acid (from precipitant head tank P-21A or P-21B) and the concentrated plutonium solution (from concentrate feed tank M-1) to the first stage precipitator (M-2). Since hydrofluoric acid is a weak acid, the solubility of plutonium (III) is a function of the $\mathrm{HNO}_{3} / \mathrm{HF}^{2}$ ratio.

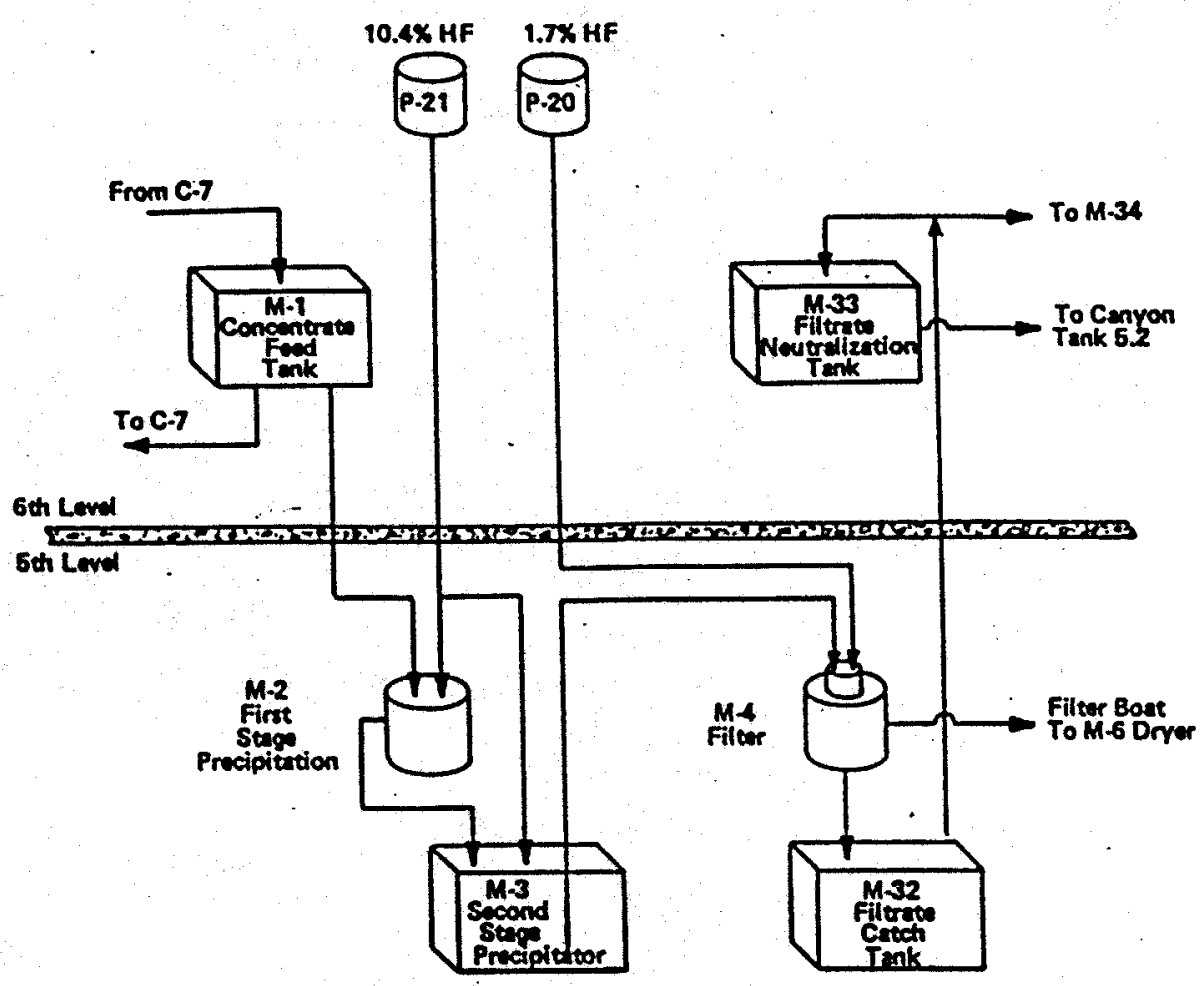


Operation of the two-stage unit is sensitive to the ratio of acids. By controlling to a low hydrofluoric acid feed rate (thereby giving a high $\mathrm{HNO}_{3} / \mathrm{HF}$ ratio), a limited number of plutonium trifluoride nuclei are formed. The solution overflows into the second stage (M-3) where sufficient hydrofluoric acid is added to lower the $\mathrm{HNO}_{3} / \mathrm{HF}$ ratio to form large plutonium trifluoride crystals and to reduce plutonium solubility. The slurry from the second stage (M3) is filtered by vacuum through a filter boat at the M-4 filter station, and the precipitate is washed with dilute hydrofluoric acid and drained to the filtrate catch tank (M-32).

Successful precipitations optimize (by controlling to a low hydrofluoric acid feed rate) the supersaturation conditions in the first stage (M-2) to avoid massive nucleation and plating. Excessive hydrofluoric acid can cause rapid nucleation and result in excessive "fines" generation which can plug filter frit and increase filtration time. Deficient hydrofluoric acid can cause the interior surfaces of the precipitator vessels to become sites for crystal growth, i.e., "plating". Plated material builds up on those surfaces and eventually flakes off resulting in plugged process lines. Periodically, a flush is required to remove the accumulated buildup of plated material.

As to the second stage (M-3), sufficient supersaturation and residence time is maintained for growing larger crystals and minimizing filtrate losses.

Following precipitation, the plutonium trifluoride cake is washed free of excess nitrate to prevent spontaneous oxidation. Once started, this oxidation reaction is autocatalytic (initiates on its own) and exothermic (gives off heat). Excess nitrate is removed by soaking the cake in a dilute hydrofluoric acid solution that is pulled (by vacuum) through the cake to M-32.

The filtrate and washes are sampled in the M-32 filtrate catch tank (fifth level). The samples are analyzed for plutonium in the liquid and solid form to determine the total plutonium concentration. If the plutonium content exceeds an established value, the filtrate is treated with an aluminum nitrate - nitric acid solution to dissolve any plutonium trifluoride solids. The resulting solution is transferred to tank M-34 for recycle through Recovery. If the plutonium content is less than the established value, the filtrate and wash solution are transferred to the M-33 tank (sixth level).

In the M-33 tanks, the solution is neutralized with sodium hydroxide. The neutralized waste solution is sampled, and tested with $\mathrm{pH}$ paper, to confirm that the solution $\mathrm{pH}$ is greater than 11 . If the $\mathrm{pH}$ is less than 11 , more sodium hydroxide is added. (If the $\mathrm{pH}$ is less than 11 and no more sodium hydroxide is added to prevent pluggage of the waste transfer lines to canyon tank 5.2., then aluminum, if present in sufficient quantity, will remain as a hydroxide precipitate and it will tend to plug these lines.) If the $\mathrm{pH}$ is greater than 11 , the waste solution is transferred to the hot canyon coating waste tank (5.2). From tank 5.2, the combined waste solution is transferred, without any evaporation, to the F-Area waste tank farm. 
In the FB-Line precipitation process, the conditions of supersaturation are controlled by the concentration of the free (uncomplexed) fluoride ion. Changes in process variables cause fluctuations in the free fluoride ion concentration. During a specific precipitation, input concentrations of feed streams do not change. Flow rates are the main process variables affecting process control. For example: an increase in the precipitant (hydrofluoric) stream flow rate results in an increase in the free fluoride ion concentration. This increase could result in increased "plating" in the first stage precipitator.

Operating experience has shown that plutonium trifluoride can be precipitated satisfactorily from nitric acid solutions. The nitric acid concentration must be controlled to avoid polymeric species of plutonium which may form at lower concentrations and result in precipitates. These precipitates frequently have undesirable properties that require recycle of the contained plutonium.

The sulfamic acid concentration must be controlled to ensure adequate reaction with any residual or rapidly induced oxidants that could oxidize plutonium (III) to plutonium (IV). Plutonium (IV) is the most stable state in nitric acid and an oxidation inhibitor (sulfamic acid) is required to hold the plutonium in the trivalent state during precipitation. An oxidation inhibitor also is needed to protect the ascorbic acid (used to reduce plutonium (IV) to plutonium (III)) from autocatalytic oxidation by the nitric acid. Generally, precipitator feed from cation exchange (coupling) eluate contains sufficient sulfamic acid to stabilize the plutonium (III). However, normal practice is to add sulfamic acid and ascorbic acid just before precipitation to ensure complete scavenging of any oxidant that might be present and reduction of any plutonium (IV) to plutonium (III).

Plutonium in the eluate from cation coupling is in the trivalent state and needs no adjustment if precipitated without delay. If there is a delay, ascorbic acid is used to adjust the precipitator feed plutonium valence. The sulfamic acid in the eluate limits oxidation of the plutonium. Eluate that is one day old may be precipitated without the presence of plutonium (IV) appreciably affecting the precipitation. Cation eluate over one day old, and other solutions containing plutonium (IV) are adjusted with ascorbic acid to reduce all of the plutonium (IV) to plutonium (III).

The ascorbic acid concentration must be controlled to ensure adequate reducing capability for feed containing predominantly plutonium (III).

When the filtration rate is poor it is not possible to maintain suspension of the precipitate between the precipitator and the filter boat. Poor filtration rates lead to settling of the precipitate, pluggage, and plating. Because of the potential, one cleanout run per day is performed to remove settled precipitate from corners of the precipitator (second stage) and to control (minimize) any oxidation of plutonium (III) to 
plutonium (IV) and hence avoid formation of plutonium tetrafluoride which is undesirable. The precipitators are flushed with a nitric acid-aluminum nitrate solution on a routine basis to remove any residual "plated" plutonium trifluoride precipitate. Aluminum must be flushed from the precipitator to prevent unacceptable aluminum contamination in the plutonium metal product.

\subsubsection{Drying and Conversion}

The filter boat containing the plutonium trifluoride is removed from the filtration station (M-4) and is transferred to the Mechanical Line air drying station (M-6). Warm, dry air is drawn through the cake to remove residual moisture (See Figure 4 - Mechanical Line Flow Diagram; Drying and Conversion). Air drying of the cake ensures conversion without excessive hydrolysis during the subsequent roasting step.

The dried cakes from two filtrations are combined in a roasting pan and charged into the roasting furnace (M-9). Residual water and other volatile materials are removed at a low initial temperature and are swept to the vessel vent system with nitrogen. At a higher temperature, a flow of oxygen blankets the cake and converts the plutonium trifluoride powder to a mixture of plutonium tetrafluoride and plutonium oxide powder. This material is hygroscopic enough to gain water if exposed to a humid atmosphere. Too rapid or excessive drying in the presence of oxygen can lead to hydrolysis. Suction air-drying and static air-drying at ambient temperatures are used to minimize the amount of hydrolysis. Roasting in a dynamic nitrogen atmosphere removes additional water while minimizing hydrolysis. Further heating in a dynamic oxygen atmosphere oxidizes the plutonium.

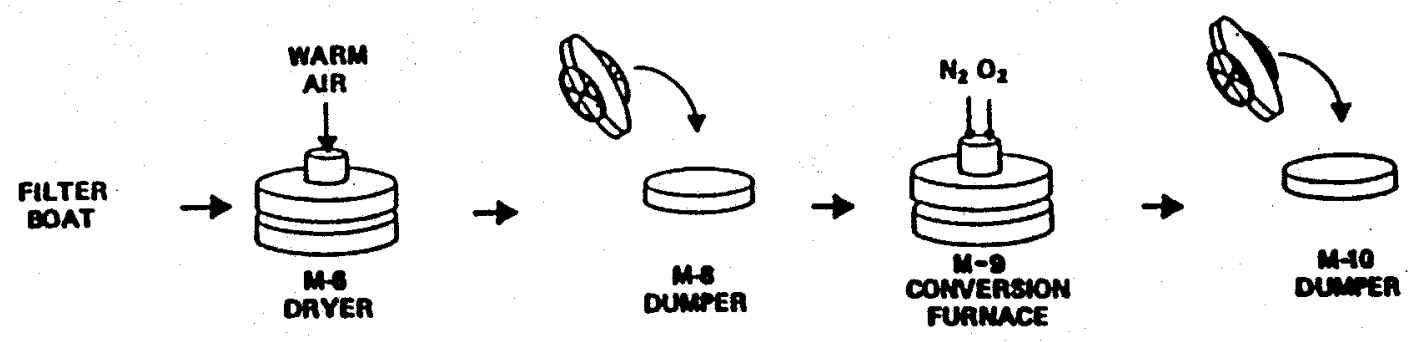

$\underline{\text { Figure } 4 \text { - Mechanical Line Flow Diagram; Drying and Conversion }}$

The atmosphere of the Mechanical Line is kept dry. The cake is removed from the M-9 furnace and transferred to the reduction furnace while exposing converted cake to the Mechanical Line atmosphere. Moisture in the Mechanical Line atmosphere will result in the sorption of "some" water. When blended with calcium metal for the reduction step, this sorbed moisture will hydrolyze a portion of the calcium metal. 
Depending upon the amount of water sorbed by the converted cake, and when the hydrolysis occurs, a variety of undesirable consequences are possible. Small amounts of moisture coupled with slow hydrolysis of the calcium metal prior to being sealed in the reduction furnace can lead to:

- Low yields of plutonium metal due to insufficient calcium metal being present for the reduction.

- Poor coalescence of the plutonium metal due to higher viscosity of the slag and the higher melting point of the slag.

- Total misfire of the reduction operation.

Greater amounts of moisture present two hazards in the reduction process:

- First, the exothermic reaction between calcium metal and moisture in the plutonium powder could, initiate certain conditions, generate enough heat to initiate the reduction reaction during the handling and mixing operations.

- Second, at the high temperatures reached during reduction, vaporized moisture could over pressurize the pressure chamber and expel material from the furnace. 


\subsubsection{Reduction}

The essential operations of the extractive metallurgical flow sheet to produce plutonium metal are reduction of the plutonium tetrafluoride - plutonium oxide mixture to yield plutonium metal and the physical separation of the reduced metal from the residue. The preparation of the roasted plutonium powder, the atmosphere to which both the plutonium powder and the calcium metal (reducing agent) are exposed, and the reduction operation are very much interdependent.

Roasted powder from the conversion step is dumped into a mixing and weighing vessel (station M-10) and then weighed on a load cell at station M-11 (See Figure 5 - Mechanical Line Flow Diagram; Reduction). The powder is adjusted (normally by adding roasted powder from a previously set-aside batch) to a predetermined weight of converted cake. When blend oxide $\left(\mathrm{PuO}_{2}\right)$ is added, it is put through an M-9 furnace drying cycle before being blended (if there is any question as to its dryness). The prepared powder is then mixed with metallic calcium (station M-13) and dumped (station M-14) into a reduction vessel (stainless steel pressure chamber containing a magnesium oxide crucible). The void space between the pressure chamber walls and the crucible is filled with magnesium oxide sand.

Converted cake is sufficiently cooled prior to the addition of calcium metal to avoid possible initiation of the reduction reaction before the pressure chamber is sealed in the reduction furnace.

The furnace charge (the plutonium powder and the calcium metal plus the pressure chamber, crucible, and sand) is alternately evacuated and purged with argon to remove any air from the reduction vessel.

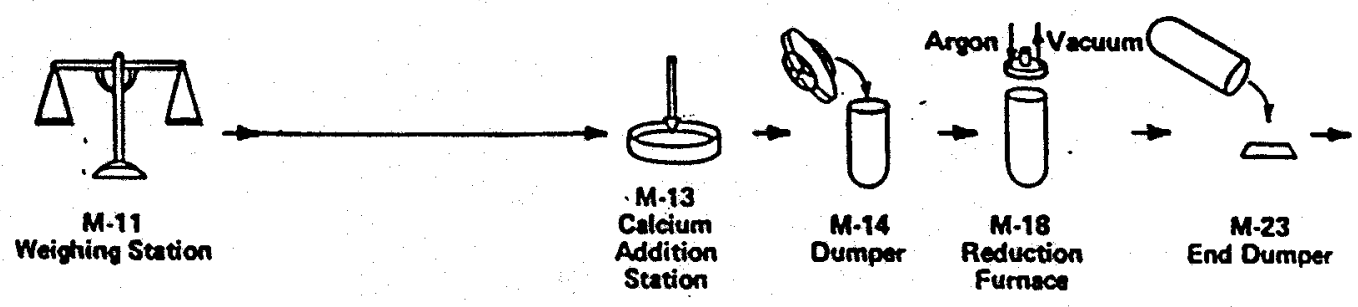

Figure 5 - Mechanical Line Flow Diagram; Reduction 
A ceramic crucible is used to contain the reaction mixture within the stainless steel pressure vessel. Contact between the metal container and the molten plutonium would result in inter-metallic reactions that would contaminate the product, reduce the yield, and render the metal pressure vessel unusable. The crucible material and the sand in which the crucible is seated are compatible with the Recovery processes. For this reason, magnesium oxide crucibles and sand are used in the reduction vessel. Heating the plutonium tetrafluorideplutonium oxide-calcium metal mixture initiates exothermic reactions.

The fluidity of the calcium fluoride-calcium oxide mixture allows the more dense plutonium liquid to separate from this mixture and flow to the bottom of the crucible forming a regulus. The calcium fluoride-calcium oxide mixture is called "slag".

The reduction crucible contents are cooled before dumping to guard against spontaneous ignition of the plutonium metal. After cooling in the ambient temperature of the Mechanical Line, the pressure chamber is opened and the charge is dumped into a catch pan. A beaker of clean magnesium oxide sand is stored at the dump station to allow the operator to immediately smother and suppress any plutonium or calcium metal fire that may occur.

The plutonium metal product is physically separated from the slag (calcium fluoride-calcium oxide mixture) and the magnesium oxide crucible. The plutonium metal is then transferred to station M-25 for "pickling" in nitric acid and subsequent water rinse. The pickling dissolves small particles of slag adhering to the metal and a passivation layer due to oxidation on the metal surface. The water rinse removes the nitric acid. Slag remaining after the reduction step is largely composed of calcium fluoride, calcium oxide, unreacted calcium metal, unreduced plutonium fluoride and oxide, and small plutonium metal droplets. Because the molten plutonium penetrates several millimeters into the wall of the magnesium oxide crucible, both the slag and crucible are packaged and stored on an interim basis, and then processed in Recovery. The pressure chamber and magnesium oxide sand is reused for other reductions. 


\subsubsection{Plutonium Metal Finishing}

The plutonium is pickled at station M-25 (Figure 6 - Mechanical Line Flow Diagram; Finishing and Packaging) to remove the adhering slag, and then rinsed in water to remove the acid. The nitric acid pickling step dissolves the slag.

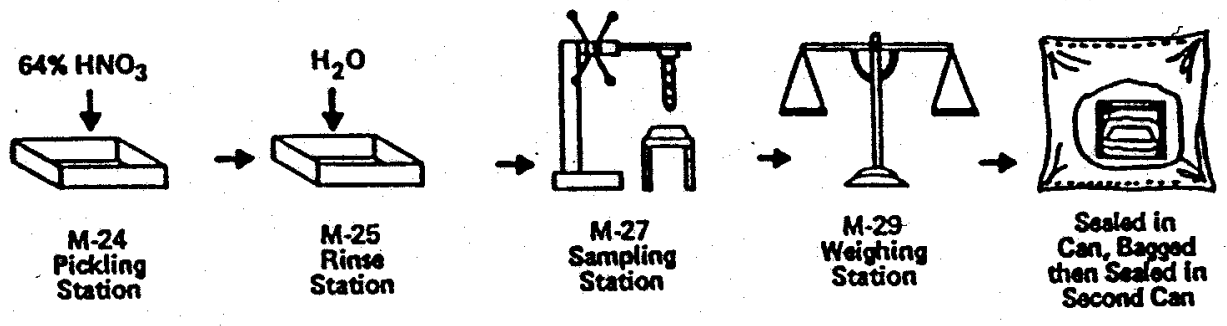

\section{Figure 6 - Mechanical Line Flow Diagram; Finishing and Packaging}

After water rinsing, the plutonium metal is allowed to air-dry before it is sampled. Samples are obtained by using a drill press. The sample, consisting of drill turnings, is sealed in a sample vial, removed from the glove box, and transferred to the 772-F Control Laboratory for analysis. After sampling and weighing, the Pu metal is placed inside a tinned steel can that is subsequently crimp-sealed. The sealed can is marked for identification and removed from the glove box in a polyethylene bag. The can is pushed to the sealed end of the bag that is attached to the glove box. Then the bag is sealed with a portable bag sealer. Canned Pu Metal product is placed inside a shipping container. The loaded shipping containers are stored in the vaults until needed. If the product purity and isotopic specifications are satisfied, the product is later shipped off-site for defense program use (i.e., fabrication into weapons shapes). Product not meeting the specifications

is returned to Special Recovery (Section 4.8) where it is dissolved and recycled to the 221-F canyon Purex process into purified plutonium nitrate solution suitable for later conversion in the FB-Line. 


\subsubsection{Recovery}

Recovery includes dissolution (e.g., slag and crucible, metal turnings, floor sweepings), filtration, anion exchange feed adjustment, and anion exchange processing (See Figure 7 - Recovery Flow Diagram). Plutonium is purified and concentrated by anion exchange after dissolving and filtering of FB-Line solid scrap materials.

Sources of plutonium bearing materials processed at special recovery include:

- $\quad$ Slag and Crucible (principle source of Recovery feedstock)

- Mechanical Line Glove Box Floor Sweepings

- $\quad$ Metal Turnings (from analytical samples)

- $\quad$ Spent plutonium metal finishing materials (Pickling Solution and Rinse Water)

- $\quad$ Filter Boat Flush and Sump Solutions

- $\quad$ ST Vacuum System Flush Solutions

- $\quad$ Precipitator Flush Solutions

- $\quad$ Recycle Solutions

Each of the three processing steps (Dissolution, Feed Adjustment and Anion Exchange) used in the Recovery Process is discussed below. Recovered plutonium solution is transferred to the 221-F canyon facility for recycle. 


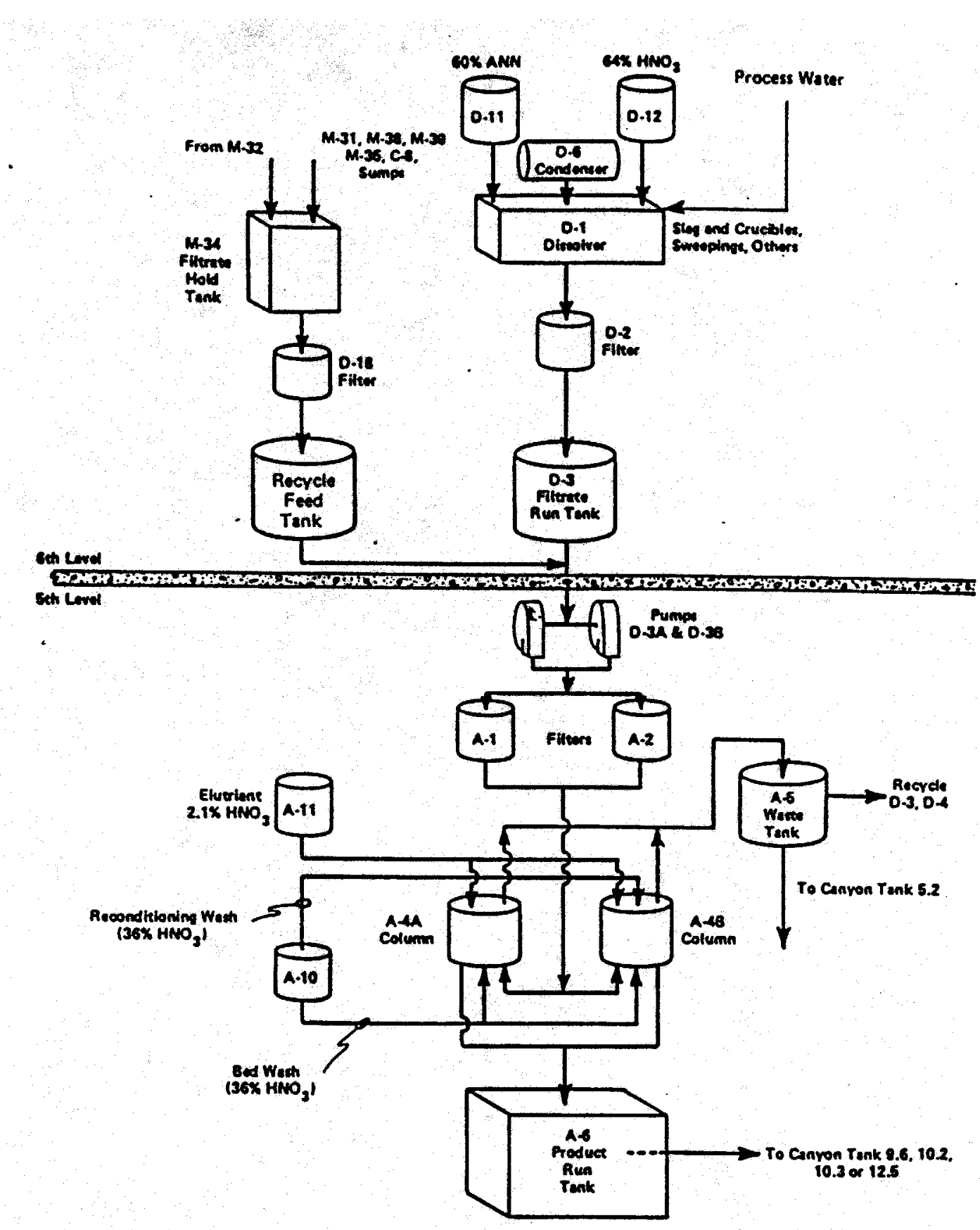

Figure 7 - Recovery Flow Diagram 


\subsubsection{Solid Scrap Dissolution}

Solid scrap consists of slag and crucible, Mechanical Line cabinet / glove box floor sweepings, and metal turnings (from analytical samples).

\section{$\underline{\text { Slag and Crucible }}$}

Aluminum nitrate nonahydrate (ANN) and nitric acid are used with heat to dissolve slag and crucible and other solids in the slab dissolver (D-1) in batches (see Figure 12). The solution is then digested to convert fluosilicic acid $\left(\mathrm{H}_{2} \mathrm{SiF}_{6}\right)$ to the less soluble silicon dioxide $\left(\mathrm{SiO}_{2}\right)$. The solution passes through primary filters (D-2) to the filtrate run tank (D-3) to remove any solids such as silicon dioxide $\left(\mathrm{SiO}_{2}\right)$ which may have crystallized. The filters are cleaned by back flushing with hot caustic $(\mathrm{NaOH})$ to the backwash tank (D-5).

\section{Mechanical Line Cabinet / Glove Box Floor Sweepings}

Plutonium powders are handled inside the mechanical line in preparation for the calciothermic reduction to plutonium metal product. In the process of handling these powders, some are spilled onto process equipment and the floor of the glove box. These powders (e.g. $\mathrm{PuF}_{3}, \mathrm{PuF}_{4}, \mathrm{PuO}_{2}$, ) are collected using a brush and scoop or hand held vacuum cleaner, screened and placed into a standard slag and crucible stainless steel container. Slag and crucible containers (maximum of four) are removed from the glove box and stored in five-gallon pails.

\section{Metal Turnings from Plutonium Metal Product Sampling}

Analytical samples consist of drill turnings removed from finished plutonium metal product. Sample material not consumed in the analyses is collected and returned to the FB-Line for recovery. Returned sample material is partially oxidized to plutonium oxide. Returned sample material is similar to slag and crucible residue (i.e., unreduced plutonium oxide and uncoalesced plutonium metal shot). For this reason, unused sample material is added along with slag and crucible material to the D-1 dissolver. 


\subsubsection{Solution Recycle}

Solutions are generated in the various FB-Line unit operations that contain plutonium concentrations in excess of discard limits. These solutions (described below) are transferred to the FB-Line recovery system and adjusted as necessary to prepare them as feed to the anion exchange columns.

\section{Boat Flush Solution}

After air drying, the contents of filter boats are dumped into roasting pans. Small amounts of plutonium trifluoride remain on the boat and filter. At station M-5, residual plutonium trifluoride is removed by dissolution with a flush of aluminum nitrate and nitric acid. Following the flush, boats are thoroughly rinsed with hydrofluoric acid to prevent possible contamination of future product with aluminum. Both the flushing and rinsing solutions are transferred to tank M-39 and is eventually routed to the Recovery process for recycle.

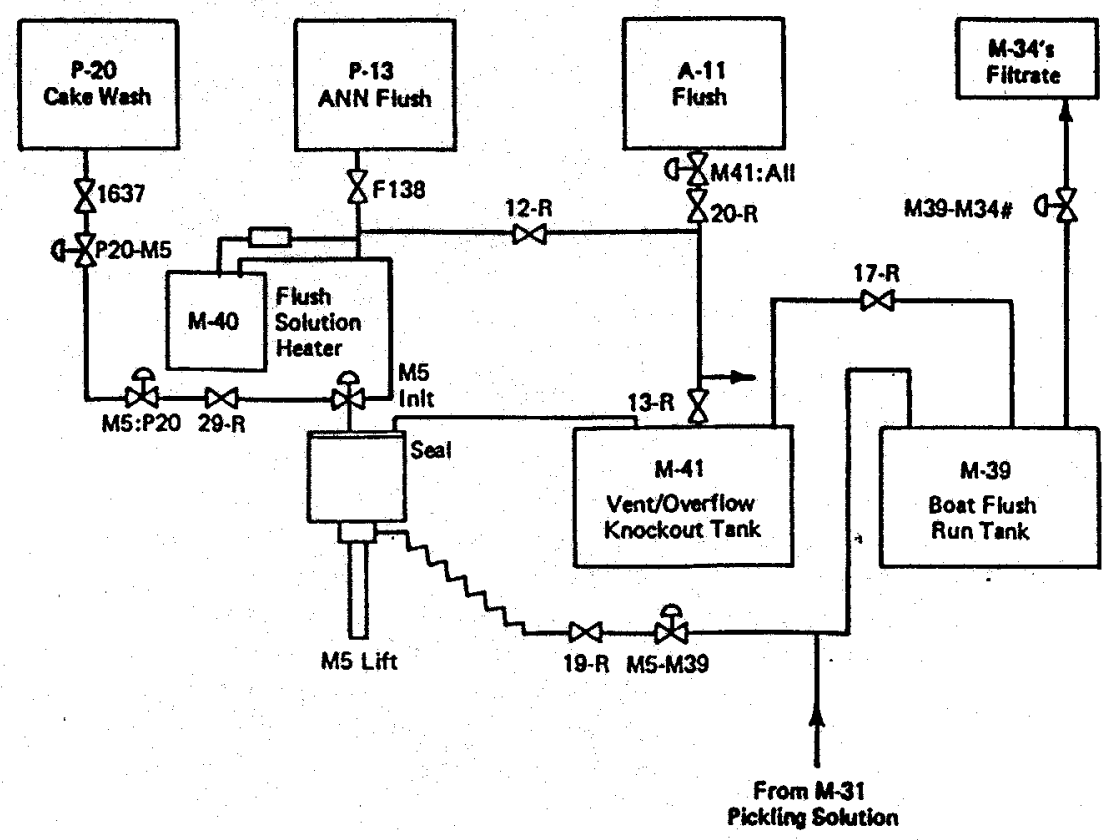

Figure 8 - Boat Flush Flow Diagram 


\section{Precipitator Flush Solution}

During operation of the precipitation unit, plutonium trifluoride deposits (plates) on surfaces of the precipitator. Some of the plutonium trifluoride sloughs off which causes plugging of lines and filters. Precipitators are flushed on a routine basis to remove the plated plutonium trifluoride deposits. A mixture of aluminum nitrate and nitric acid is used to perform the flush, followed by a nitric acid and a water rinse. The precipitator flush solutions are routed to tank M-34 prior to adjustment as anion feed solution in tank D-4.

\section{$\underline{\text { Sump Solutions }}$}

Sumps are provided under each process tank to catch and contain any overflow solution leaking from the tank or process line(s). When solution is found present in sumps, it is transferred to a hold tank (M-34A, M-34B, C-8 or M-35). A sample of the solution is examined for the presence of solids and analyzed for plutonium content, $\mathrm{pH}$ and other chemical constituents. Depending upon sample analysis results, the solution is routed to either waste or to the anion feed adjustment tank (D-4). If solids are present, they are dissolved either in the sump or a hold tank. If dissolution is not practical, the solids will be physically removed and stored until a procedure is developed for dissolution in Special Recovery.

\section{Process Vessel Vent System Solution}

All process vessels are vented through a system designed to prevent carryover of entrained liquids. Scrub tanks V$6 \mathrm{~A}$ and $\mathrm{V}-6 \mathrm{~B}$ are periodically drained, sampled and the solution routed to waste.

\section{Plutonium Metal Pickling and Rinse Water Solution}

After being physically separated from the slag and crucible, the plutonium metal is pickled in nitric acid to remove any adherent slag. Following the pickling operation, the metal is rinsed with water to remove any residual acid. 


\section{$\underline{\text { Recycle Solutions }}$}

Solutions containing recoverable plutonium are generated during both laboratory quality control and research and development activities. Solutions are contained in either one or two-liter bottles inside metal five-gallon pails for transfer from the laboratories to the FB-Line Recovery. Solutions are handled on an individual basis depending on the constituents in the solution. In general, those solutions that do not contain any of the halogens (chlorine, bromine or iodine) can be added directly to the D-1 dissolver solution during a slag and crucible dissolution cycle. Solutions containing halogens other than fluoride must have the halogen removed prior to processing in the Recovery system.

\subsubsection{Solution Collection}

In general, all liquid recycle generated within FB-Line requiring anion exchange processing is transferred from their point of origin to the M-34 tanks, sampled and analyzed then transferred to recovery tank D-4. The solutions are adjusted as necessary to prepare the feed for anion exchange purification and Recovery. Slag and crucible dissolver (D-1) solutions are also processed through anion exchange. Anion exchange (verses cation exchange) is the process of choice for these solutions because of the presence of other major cation impurities like $\mathrm{Ca}^{+2}, \mathrm{Mg}^{+2}$, and $\mathrm{Al}^{+3}$. Even though this solution is quite high in fluoride ion, the presence of $\mathrm{F}^{-1}$ is negated due to complex formation by aluminum resulting in $\mathrm{AlF}^{+2}$, which is a cation and does not compete for active resin sites.

\section{Feed Adjustment for Anion Exchange Processing}

The filtrate in tank D-3 may be chemically adjusted by adding ferrous sulfamate to reduce all plutonium (VI) $\left(\mathrm{PuO}_{2}^{+2}\right)$, if present, and plutonium (IV) $\left(\mathrm{Pu}^{+4}\right)$ to plutonium (III) $\left(\mathrm{Pu}^{+3}\right)$. This adjustment is followed by sodium nitrite to reoxidize all of the plutonium to the plutonium (IV) $\left(\mathrm{Pu}^{+4}\right)$ state as needed for anion exchange. Making these adjustments forms the plutonium into a hexanitratoplutonium (IV) complex ion $\left(\mathrm{Pu}\left(\mathrm{NO}_{3}\right)_{6}{ }^{-2}\right)$. Normal operation currently does not require this adjustment step. The plutonium in D-4 is oxidized with sodium nitrite to assure that it is in the +4 valence state; no ferrous sulfamate is added. The solution is pumped through filters (A-1 or A-2) and then to the ion exchange column (A-4A or A-4B). 
Operation of the Anion Exchange System

Anion exchange is a separation process used to separate desirable from undesirable anions. In the FB-Line the desirable anion is hexanitratoplutonium nitrate complex ion; the undesirable anions are the numerous metallic anion and cation impurities. Recovery dissolver solution is transferred by vacuum to the filtrate run tank D-3. This tank in turn feeds the anion exchange columns cycle (See Figure 9 - Anion Exchange Flow Diagram). After solution adjustment (as described above), a plutonium solution batch is pumped from the D-3 tank through filters A-1 or A-2 to the anion exchange column A-4A or A-4B. The plutonium nitrate anion complex is absorbed on the resin as the adjusted feed solution passes through the column. Sorption of plutonium onto the resin is inversely proportional to the solution flow rate through the column.

Anionic and cationic impurities pass through the anion exchange column to waste tank A-5. This waste solution (called ion column effluent) flows to tank A-5 where a sample is drawn and analyzed. If analysis determines plutonium concentration within discard limits, the effluent is transferred to canyon waste tank 5.2.

For additional purification, remaining impurities are washed from the column by passing a wash solution of nitric acid from tank A-10 upward through the column to waste tank A-5. This solution is also transferred to canyon tank 5.2.

Plutonium is eluted from the column by a downward flow of weak nitric acid followed by a strong nitric acid reconditioning wash. The eluate empties to the product run tank A-6 where a sample is drawn and set to the laboratory for analysis. Results from the laboratory analysis are used to determine whether the solution is transferred to canyon tank 10.2 or 10.3 (first plutonium cycle) or tank 9.6 (second plutonium cycle).

The anion exchange resin may contain gases $\left(\mathrm{NO}_{\mathrm{x}}\right)$ generated by nitric acid decomposition. These gases normally escape through the facility vessel vent system.

Spent resin to be discarded is treated to convert any remaining nitrate to sulfate form. The conversion is accomplished by treating the used resin with sodium sulfate solution so that the nitrate ion is replaced by the sulfate ion. Following the sulfate wash, the resin is washed with water to remove residual sulfate. The washed and treated resin is changed-out, bagged and removed from the glove box. The waste resin is then packaged for transfer to the Savannah River Site waste storage facility. Resin is not part of this waste stream. 


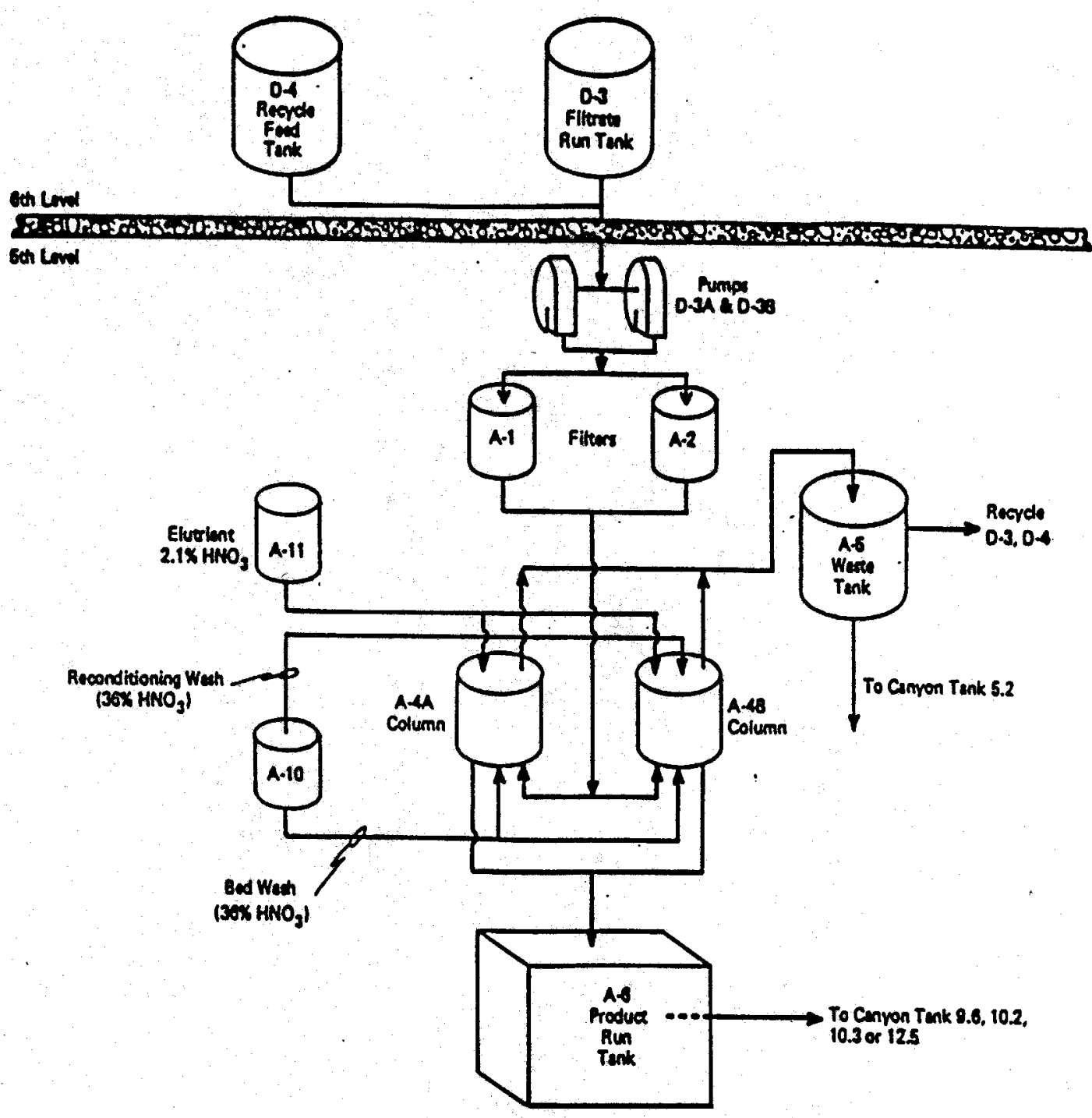

Figure 9 - Anion Exchange Flow Diagram 


\subsubsection{Special Recovery}

Plutonium was recovered from solids received from both onsite and offsite and when the material was not suitable for processing in the slag and crucible dissolver (D-1) in the Special Recovery line. High-grade plutonium scrap (i.e., plutonium metal or oxide that did not meet specifications) and low-grade scrap plutonium were dissolved or leached in the Special Recovery facility. Two processing lines were used at Special Recovery. One line (designated cabinets 1-5) was devoted to plutonium metal dissolution (See Figure 10 - Special Recovery Flow Diagram; Metal Dissolution Process.) and the other (designated cabinets 6-8) for plutonium oxide dissolution (See Figure 11 - Special Recovery Flow Diagram; Oxide Dissolution Process.). Operation of cabinets 1-5 was suspended in 1986 - 1987 and placed in a "lay-up" condition. According to the FB-Line Process Systems Engineering Manager, only Low-Level waste was generated between the time the facility was placed in lay-up status and March 1998. Records were reviewed to determine whether cabinets 6-8 were operational during the time of generation of this waste stream. Off-site scrap material was processed in cabinets 6-8 between January 1990 and October $1991^{101}$. Specifically, material from Hanford (MC\&A Account \#HUD3, Fuel Grade Pu Oxide, received at the SRS in 1990) and Rocky Flats (MC\&A Account \#ARF243, Pu Oxide, received at the SRS in 1985) was dissolved in these cabinets. Records indicating whether the Rocky Flats material was weapons or fuel grade were unclear. The solute from these scrap materials was recycled to the F-Canyon. This was the last campaign of off-site material to be processed in Special Recovery. Nine waste "cuts" were identified to have been removed from cabinets 6-8 since January $1990^{101}$. 


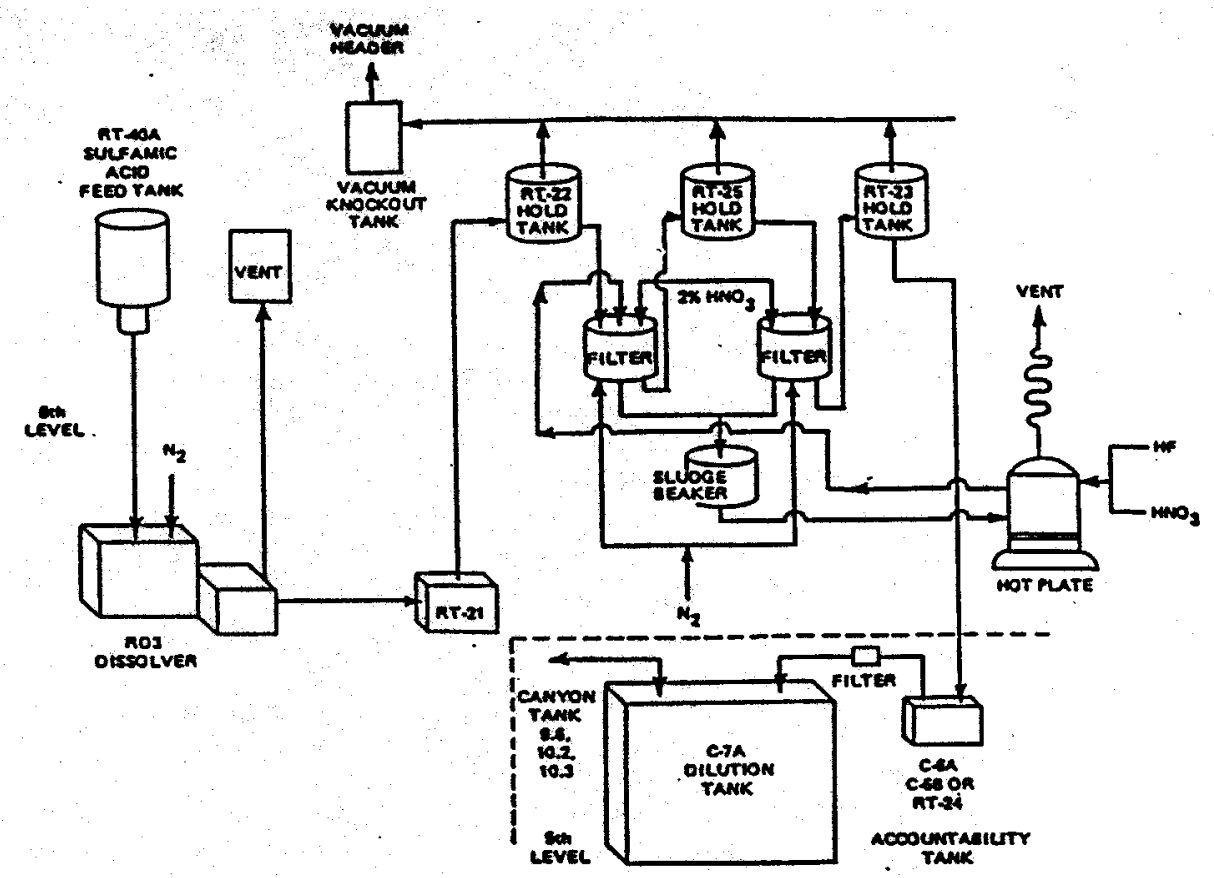

$\underline{\text { Figure } 10 \text { - Special Recovery Flow Diagram; Metal Dissolution Process }}$

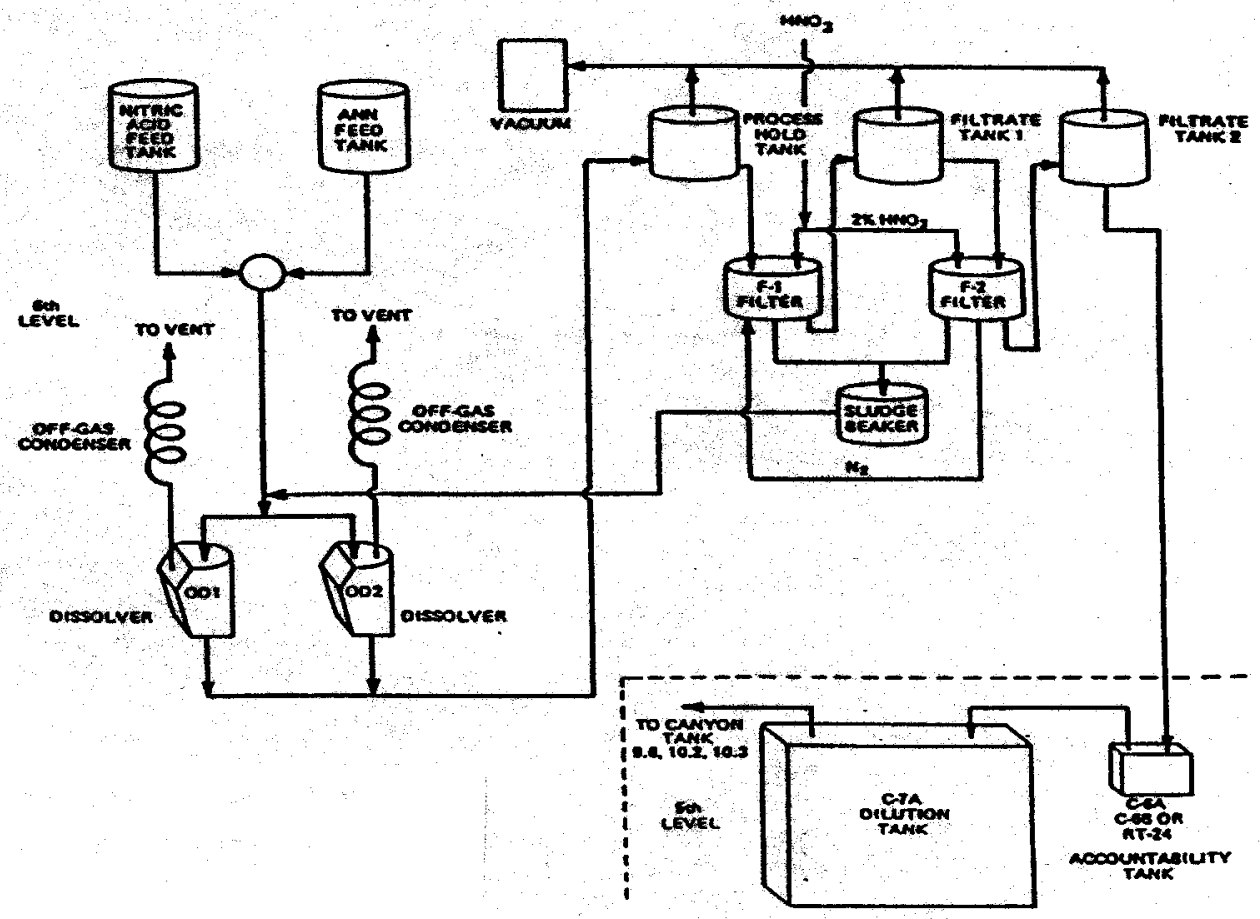

Figure 11 - Special Recovery Flow Diagram; Oxide Dissolution Process 


\subsection{Waste Identification and Characterization}

Management of transuranic waste from the FB-Line facility was/is achieved as directed by procedures ${ }^{11-64}$ designed to ensure accurate characterization and identification of the waste at the point of generation. Transuranic waste certification activities at the Savannah River Site were audited by the Albuquerque Operations Office WIPP Waste Acceptance Criteria Certification Committee three times prior to the initial generation of this waste stream. The most recent audits were conducted in February 1988 and September 1989. Each of these audits determined that the waste certification program in place was "effective and well managed" 99 and that the Savannah River Site was approved to certify transuranic waste to WIPP requirements. The procedures in place today (within the FB-Line facility) are essentially identical to those in place in 1990 when generation of this waste stream began. These procedures direct facility personnel actions to ensure storage in accordance with the Savannah River Site Solid Waste Division Waste Acceptance Criteria ${ }^{65}$ and WIPP Waste Acceptance Criteria ${ }^{66}$ in effect at the time of waste packaging. Waste is examined for physical content against criteria listed in the procedure(s) to determine and assign the appropriate "local" waste category code (i.e., 001-Job Control [see Section 5.5], 002-Sludge, 003-Resin, 004-Filters, etc.). Facility personnel also determined whether or not the waste was hazardous under the Resource Conservation and Recovery Act (RCRA). Personnel responsible for identification and packaging of waste were RCRA trained. Using procedures (see Section 4.1.6) and knowledge from the training, the identified waste category and applicable hazardous / non-hazardous determination was recorded on a "Waste ID Slip" for each waste parcel generated. The "Waste ID Slip" is an internal worksheet that captures information necessary for completion of the "TRU Waste Data Package" (OSR 7-872) ${ }^{96}$ form and "Radioactive Solid Waste Burial Ground Record" (OSR 7-375A) ${ }^{97}$. These forms were completed at the time the waste was placed in a drum liner / drum. Each form (record which contains a statement attesting to the accuracy of the information) accompanied waste containers (i.e., drums) when transported from the FB-Line to the Solid Waste Division storage facility. Completed forms for each waste container to be characterized for disposal at the WIPP are stored in the WIPP Records Facility at the SRS. Waste drums were labeled (paint stenciled) to reflect information as to whether they were WIPP certifiable (i.e., 001-Job Control waste containing no sludge, resin or filters) and whether they contained hazardous constituents. This labeling provides a visual indicator to aid personnel moving and storing the drums. Each drum is traceable to it's respective generating facility and characterization via a unique File Sequence Number (FSN). This serialized number appears on each of the OSR forms and on each waste drum and inner liner. Each drum and liner is identified with its FSN using a die stamped stainless steel tag attached with wire. 


\subsection{Waste Certification Procedures}

Over the period of waste generation as discussed in Section 5.2, FB-Line personnel used procedures (listed below) to package, identify and document transuranic waste generated from the FB-Line. Through completion of the procedures, personnel ensured that waste contents are known, documented and that the container was labeled accordingly. Waste containers were identified as "certifiable" or "non-certifiable" in accordance with previous versions of WIPP Waste Acceptance Criteria (i.e., revisions 3, 4 and 5). At the Savannah River Site, the designation of "certifiable" denoted that the waste/container was "job control waste" that contained no WIPP prohibited items/materials and that the waste was suitable for later certification and shipment to the WIPP. The procedures provided personnel with specific information and instructions concerning hazardous materials that could be encountered, WIPP prohibited items/materials and acceptable methods for absorption of liquids and neutralization of acids and bases. Each "TRU Waste Data Package" (OSR 7-872) ${ }^{96}$ contains a statement signed by the generator such that the waste has been verified to be "certifiable" or "non-certifiable" in accordance with the WIPP Waste Acceptance Criteria in place at the time. FB-Line personnel use the following procedures to manage transuranic waste generated in the facility.

- DPSOL 221-FB-2502, Packaging General and Cabinet Waste Into Red Pails ${ }^{11-21}$

- DPSOL 221-FB-2504, Drumming Red Waste Pails and Shipment to the Burial Ground ${ }^{22-32}$

- SOP 221-FB-2505, Packaging TRU (Process Cabinet) Waste Into A Drum Liner ${ }^{33-47}$

- DPSOL 221-FB-2506, Packaging TRU Waste (Excluding Process Cabinet Waste) Into A Drum Liner ${ }^{\text {48-64 }}$ 


\subsection{REQUIRED WASTE STREAM INFORMATION}

\subsection{Area and Building From Which the Waste Stream Was Generated}

All waste from these streams was generated from the FB-Line facility located inside the 221-F separations canyon building. Waste was generated from areas inside process cabinets or glove boxes or from areas contaminated with radioactive material (estimated to be TRU levels) adjacent to the process cabinets / glove boxes.

\subsection{Waste Stream Volume and Period of Generation}

All waste in these streams was generated after January 25, 1990 and before March 20, 1997. Fifty-nine (59) 55gallon drums of waste from these streams have been identified. A listing of containers ${ }^{68}$ for each of these waste streams is on file in the SRS WIPP Records Facility in Building 642-E.

\subsection{Correlation of Waste Streams Generated from the same Building and Process}

These waste streams are a MTRU counterpart of waste stream SR-T001-221F-HET and SR-W027-221F-HET. Acceptable Knowledge for the "T001" and "W027" waste streams was previously documented in WSRC-TR-9800301, “Savannah River Site Waste Isolation Pilot Plant Disposal Program Acceptable Knowledge Summary Report For Waste Stream: SR-T001-221F-HET” and CCP-AK-SRS-1, “Central Characterization Project, Acceptable Knowledge Summary Report For Savannah River Site Waste Streams: SR W027-221F-Het-A through Het-E" respectively. The correlation between waste streams with regard to time of generation, waste processing, and site specific facilities are delineated in the Savannah River Site chapter of the Transuranic Waste Baseline Inventory Report ${ }^{1}$ (TWBIR). This delineation is based on a technical report titled SRS Data Preparation For The 1995 TRU Waste Baseline Inventory Report, Mixed Waste Inventory Report, and Integrated Database ${ }^{69}$. The TWBIR contains 47 SRS generator specific waste streams: 29 mixed-TRU and 18 TRU. For example, waste stream number SR-T001-221F-HET was created from TWBIR Site Waste Stream Number SR-T001 and Building 221-F at SRS. The "HET" indicates that the final waste form consists of heterogeneous debris. . Similarly, the waste stream numbers for the streams described in this document are "SR-W026" from the TWBIR, "221-F" for the generating facility, and "HET" for heterogeneous debris.

Drums are traceable to the generating facility and process, and time of generation via a unique FSN. This number appears on each of the OSR forms (see 4.3 above) and on a die stamped stainless steel tag attached to each drum with wire. 


\subsection{Waste Generating Activities}

Much of the work performed in FB-Line takes place within areas contaminated with radioactive material. Waste materials and items contained in this stream result from various activities that take place in these areas. Routine operational activities (surveillance rounds, process equipment adjustments, radiological surveys, etc.) and preventive and corrective maintenance were the major producer of the waste in this stream. Other contributing activities included facility modifications, decontamination and housekeeping (i.e., cleanup) tasks. Examples of activities resulting in waste other than used personal protective equipment include; absorption of liquids, glove replacement on process cabinets / glove boxes, various mechanical and electrical repairs, maintenance, and change outs. 


\subsection{Type of Waste Generated}

Waste contained in drums from this waste stream is a heterogeneous combination of dry organic and inorganic debris that includes RCRA hazardous debris. At the Savannah River Site this is known as "Job Control Waste". The job control waste in this stream could contain any item / material that was discarded because it was no longer useable or no longer needed, and

- Was not resin or sludge, and

- Met Savannah River Site and WIPP Waste Acceptance Criteria.

More than 2100 drums from this and the mixed transuranic waste stream were radiographed during the Container Examination and Evaluation Program (CEEP) ${ }^{95}$ (See Section 6.0 below.). Review of the radiographers' log from this program provided useful information concerning contents of drums from this waste stream. Examples of items / materials observed to have been packaged into this waste stream are listed below.

$\begin{array}{llll}\text { Plastic Bags } & \text { Plastic Suit (PPE) } & \text { Breathing Air Hose } & \text { Metal Cans } \\ \text { Absorbent } * & \text { Scissors } & \text { Pipe / Valves } & \text { Flashlight } \\ \text { Flashlight Battery(s) } & \text { Sheet Metal } & \text { Aerosol Cans } & \text { Paint Can } \\ \text { Pipe Flange } & \text { Electric Drill } & \text { Electric Grinder } & \text { Electrical Wire } \\ \text { Cloth Coveralls (PPE) } & \text { Scaffold Hardware } & \text { Nuts, Bolts \& Washers } & \text { Saw Blade } \\ \text { Plastic Sheeting } & \text { Wrench } & \text { Rolls of Tape } & \text { Light Bulb } \\ \text { Hammer } & \text { Plastic Bottles } & \text { Ladder (cut up) } & \text { Tape Measure } \\ \text { Safety Harness (PPE) } & \text { Metal Bucket } & \text { Wood / Nails } & \text { Wire Mesh } \\ \text { Hack Saw } & \text { Respirator (PPE) } & \text { Plastic Tubing } & \text { Drill Bits } \\ \text { Leaded Gloves } & \text { Cadmium Metal } & \text { Fluorescent Light Bulbs } & \text { Hg Thermometers }\end{array}$

*NOTE: Absorbents used in the FB-Line were Celite ${ }^{107}$, Soda Ash ${ }^{106}$ and Oil-Dry ${ }^{105}$

Approximately 400 containers from the sister waste stream SR-T001-221F-HET (See Section 5.3) were radiographed as part of the WIPP characterization process. Review of RTR/X-Ray Container Data Forms documenting results of the radiography substantiated the above listing as to the kinds of debris waste expected in these streams.

The following Waste Material Parameters (from Table B3-12) are present in these waste streams: Iron-based metals/alloys, Other Metals, Other Inorganic Materials, Cellulosics, Rubber, Plastics (waste materials), Steel (packaging materials) and Plastics (packaging materials). 


\subsubsection{Material Inputs Related to Physical Form, Chemical and Radiological Waste Characteristics}

Physical Form: The following listing of materials / items are included in FB-Line procedures as "Job Control Waste" which were shipped to the Solid Waste storage facility as "certifiable" transuranic waste.

"Certifiable" "Job Control Waste" described in FB-Line Waste Procedures ${ }^{11-64}$

“Organic: BH-38 cleaner, bleach, breathing-air hose, carboy bottles, cartons, Celite ${ }^{\circledR}$, cloth, craft paper, crucibles, drum liners, dry box gloves, electricians tape, firebrick, fresh-air hoods, glassware, gloves, hut plastic, Isoclean ${ }^{\circledR}$, leather, masking tape, miscellaneous rubber, miscellaneous wood, mop heads, nylon-filled tape, oil, paint, paper, plastic film, plastic tape, plastic shoe covers, plastic suits, Plexiglas ${ }^{\circledR}$, poly bags, PVC bags, rags, sheeting, sponges, spray, surgeons gloves, tape, uniforms, welder's jacket, swipes, etc."

"Inorganic: agitator motors, agitators, button cans, cadmium sheet, calcium, ceramics, glass, hot plates, instruments, lab ware, leaded aprons, lead bricks, mercury thermometers, metal and glass beakers, metal hardware, metal tubing and fittings, miscellaneous metal cans, motors, scales, off-plant oxide containers, oxide cans, pipe, slag and crucible cans, shipping containers, spray cans, tools, valves, valve handles, etc.”

Waste in these streams consists of a heterogeneous mixture of:

- Plastics (e.g., bags and sheeting for contamination containment and control, personal protective equipment)

- Cellulose / cellulose based material (e.g., paper wipes, rags, laboratory coats, coveralls)

- Ferrous and non-ferrous metals (e.g., containers, tools, piping, valves)

- Rubber products (e.g., gloves, gaskets, seals)

- Absorbent materials (e.g., diatomaceous earth (i.e., Celite $\left.{ }^{\circledR}\right)$ )

- Absorbed liquids (e.g., flush water, neutralized acid / caustic solutions)

Job control waste at the SRS equates to Summary Category Group S5000.

Waste Matrix Code "S5440" has been assigned to these waste streams based on review of OSR 7-872 "TRU Waste Package Data" forms and empirical data gleaned from radiography results of sister waste stream SR-T001-221FHET. Waste Matrix Code S5440 "Predominantly Organic Debris" is defined as:

Waste streams that are estimated to contain a greater amount of organic debris materials than any other type of material. The balance of the matrix may be inorganic debris materials (i.e., metal, inorganic nonmetal), soil, or homogeneous solids. The volumetric mix of organic and inorganic debris may vary on an individual container basis. 


\subsubsection{Radiological Characterization}

In July 1994, an extensive radioisotope characterization ${ }^{74}$ (based on Process Knowledge) of Low-Level waste from the FB-Line was completed. Results of the characterization were later validated ${ }^{75}$ (November 1995) through laboratory analysis of smear samples ${ }^{76}$ obtained from various locations throughout the FB-Line facility. Some "fuel grade" material was processed in the FB-Line ${ }^{101}$, however it represented such a small portion of the overall radionuclide matrix that it is negligible. During the period of generation for this waste stream, off-site plutonium oxide material from Hanford was processed in the Special Recovery area of FB-Line (see 4.2.7 above). Additionally, off-site weapons grade and fuel grade plutonium oxide and weapons grade plutonium metal was repackaged in the Mechanical Line Finishing and Packaging cabinet. A technical discussion concerning impact of fuel grade material in the weapons grade waste stream is contained in WSRC-TR-94-0288, Radioisotope Characterization of FB-Line Low-Level Waste ${ }^{74}$. The majority of waste from the FB-Line uses a nominal isotopic distribution documented in the FB-Line Basis for Interim Operation ${ }^{10}$. This distribution (shown below in Table 1221FB-Line WG Pu Isotopic Distribution) was determined through years of operating experience and sample analyses.

\section{Table 1 - 221FB-Line WG Pu Isotopic Distribution}

\begin{tabular}{|c|c|c|}
\hline Isotope & Wt \% & $\begin{array}{c}\text { Isotopic } \\
\text { Range }^{\mathbf{1 1 1}} \\
\text { (Wt \%) }\end{array}$ \\
\hline${ }^{238} \mathrm{Pu}$ & 0.010 & $0.00-0.05$ \\
\hline${ }^{239} \mathrm{Pu}$ & 93.47 & $93.05-95.00$ \\
\hline${ }^{240} \mathrm{Pu}$ & 5.72 & $5.00-6.50$ \\
\hline${ }^{241} \mathrm{Pu}$ & 0.774 & $0.00-0.75$ \\
\hline${ }^{242} \mathrm{Pu}$ & 0.026 & 0.00 to less than 0.10 \\
\hline${ }^{241} \mathrm{Am}$ & Daughter of ${ }^{241} \mathrm{Pu}$ & Age \& ${ }^{241} \mathrm{Pu}$ dependent \\
\hline
\end{tabular}

Review of Radioactive Solid Waste Burial Ground Records ${ }^{97}$ indicates that some of the waste will manifest an isotopic distribution different from that shown in Table 1. The different distribution resulted from those activities using off-site fuel grade material (as discussed above) and the fact that the waste was not segregated (or homogenized) on an isotopic distribution basis. 
Table 2 - 221FB-Line Alternate Pu Isotopic Distribution shows this different distribution. Americium-241 is also present in the waste as a result of in-growth from the beta decay of ${ }^{241} \mathrm{Pu}$. The quantity is present in relation to the age and amount of ${ }^{241} \mathrm{Pu}$ in the waste regardless of the distribution. At the time of generation, greater than $99.99 \%$ of the radioactivity in the waste stream is contributed by plutonium isotopes.

\section{Table 2 - 221FB-Line Alternate Pu Isotopic Distribution}

\begin{tabular}{|c|c|}
\hline Isotope & $\begin{array}{c}\text { Isotopic } \\
\text { Range } \\
\text { (Wt \%) }\end{array}$ \\
\hline${ }^{238} \mathrm{Pu}$ & $0.00-0.05$ \\
\hline${ }^{239} \mathrm{Pu}$ & $84.0-90.0$ \\
\hline${ }^{240} \mathrm{Pu}$ & $10.0-13.5$ \\
\hline${ }^{241} \mathrm{Pu}$ & $0.0-2.0$ \\
\hline${ }^{242} \mathrm{Pu}$ & 0.0 to less than 0.2 \\
\hline${ }^{241} \mathrm{Am}$ & Daughter of ${ }^{241} \mathrm{Pu}:$ Age \& ${ }^{241} \mathrm{Pu}$ dependent \\
\hline
\end{tabular}

\subsubsection{Chemical Content Identification}

Since 1990, the procurement and use of chemicals containing hazardous constituents (under the RCRA) have been administratively controlled by procedure ${ }^{77-78}$. Under this procedure, blue circular labels ("blue dots") were affixed to chemical containers which if disposed in an untreated or non-empty condition could constitute hazardous or mixed (if radiologically contaminated) waste. A listing of all chemicals used in the FB-Line is maintained along with the facility Material Safety Data Sheet and denotes which chemicals are "blue dot" and which are not. The blue dot serves to alert facility personnel that if a chemical is no longer needed, it may require treatment prior to disposal or may be required to be disposed as hazardous/mixed mixed waste as appropriate.

\section{F-Listed Solvents}

Transuranic waste generated prior to January 25, 1990 is managed as mixed transuranic waste for F-Listed solvent $^{70}$. As stated in Section 5.2 above, the subject waste stream was generated after January 25, 1990. After this date, Savannah River Site generators segregated F-Listed debris (i.e., solvent contaminated rags and wipes) from other non-solvent debris waste. No waste in these streams is identified as containing F-Listed solvent. Empirical data from headspace gas sampling of sister waste stream SR-T001-221F-HET determined that the UCL $\mathrm{U}_{90}$ value for 1,1,1-Trichloroethane exceeded the WIPP waste analysis plan Program Required Quantitation Limit (PRQL). Reevaluation of acceptable knowledge in accordance with WIPP requirements determined that the compound was 
present as a result of packaging practices and does not constitute a hazardous waste under RCRA. Therefore no FList hazardous waste numbers are assigned to any of the containers in these waste streams.

\section{Ignitables, Reactives, and Corrosives}

The TRU Waste Package Data Form for each drum was reviewed prior to inclusion on the candidate drum list to ensure that the FB-Line generator documented that the waste matrix does not contain ignitable, reactive, and corrosive waste. The TRU Waste Data Package Form is completed according to SOP 221-FB-2504-NS ${ }^{22-32}$. FBLine operating procedures direct that residual acids or bases in TRU waste are neutralized, and any corrosive, ignitable or reactive characteristics are removed (through absorption or neutralization) before waste is packaged and transported to the solid waste storage facility.

\section{$\underline{\text { Metals }}$}

The following metals (which exhibit the characteristic of toxicity or *reactivity) are present in the FB-Line: Cadmium, Chromium, *Calcium, Lead and Mercury. Waste management procedures used by FB-Line personnel ensure that these metals are managed and disposed appropriately as mixed TRU. In the case of calcium metal, this material is rendered non-reactive prior to disposal. The TRU Waste Package Data Form for each drum was reviewed prior to inclusion on the candidate drum list to ensure that the FB-Line generator documented that the waste matrix did not contain metals that exhibit the characteristic of reactivity. Most of the fifty-nine drums in these waste streams were identified by the waste generator to exhibit the characteristic of toxicity for metals. An additional seventeen (17) drums were reassigned from waste stream SR-T001-221F-HET to one of the waste streams delineated herein based on radiography results. The following hazardous waste number(s) were assigned as applicable to each of the drums: D008, lead from leaded glove box gloves; D007, chromium from a mechanical line ventilation duct cleanout; D009, mercury from discarded fluorescent light bulbs; and D006, cadmium from discarded shielding material.

\section{Explosive}

Explosives are not permitted in transuranic waste. Generators explicitly stated whether (or not) waste drums transferred to the SRS storage facility contained an explosive item/material through completion of the TRU Waste Date Package Form ${ }^{96}$. The TRU Waste Data Package Form for each drum was reviewed (by the AK Investigator) to ensure that the FB-Line generator documented that waste shipped did not contain explosives.

One explosive device was recognized during compilation of acceptable knowledge information for the FB-Line. Electrical Discharge Plugs (also known as squibs) are used in Halex ${ }^{\circledR}$ fire suppression systems ${ }^{6}$ located in the FBLine facility. Each squib consists of a small smokeless powder charge sealed in a copper thimble inside a threaded metal housing/coupling. This assembly is electrically connected to fire detection sensors located throughout the 
facility. In the event of actuation during service, the charge detonates to rupture a disk membrane that releases fire suppression agent. Squibs were replaced on a five-year frequency. The first known change out occurred in 1987. According to FB-Line facility personnel, the squibs are located within radiological contamination areas, but are not located within glove boxes or cabinets ${ }^{104}$. It was further stated that waste from these areas is usually low-level waste, and that this low-level waste would not be disposed as transuranic waste. The TRU Waste Data Package Form $^{96}$ for each drum is reviewed to ensure that the FB-Line generator documented that waste matrix does not contain explosives in the waste and that the Waste Description Code is for "Job Control Waste" only.

\section{Free Liquid}

Any free liquids disposed from the FB-Line as transuranic waste were absorbed on appropriate absorption media. Absorption of free liquid was directed by FB-Line procedures prior to placement in a TRU waste container. FBLine operating procedures direct that free liquid was not to be placed in transuranic waste containers. The TRU Waste Package Data Form ${ }^{96}$ for each drum was reviewed by the Acceptable Knowledge Investigator to ensure that the FB-Line generator documented that waste does not contain free liquids.

\section{Pyrophoric}

FB-Line operating procedures direct that pyrophoric materials not be placed in transuranic waste containers. The TRU Waste Package Data Form for each drum was reviewed by the Acceptable Knowledge Investigator to ensure that the FB-Line generator documented that waste in these streams does not contain pyrophoric material.

\section{Chelating Agents and Complexants:}

These waste streams may contain some chelating agents in the form of spent decontamination material. Two commercial decontamination products, Stripcoat $\mathrm{TLC}^{\circledR 108}$ and Stripper $\# 44^{\circledast}$ were used in the FB-Line facility to remove radioactive contamination from room surfaces. Use of the products was sporadic, and according to facility personnel the spent product could have been disposed in either this waste stream, or the FB-Line low-level waste stream depending on the concentration of contamination removed. Review of the Material Safety Data Sheets for Stripcoat TLC $^{\circledR}$ and Stripper $\# 4^{\circledR}$, determined that these decontamination products contain EDTA (a known chelating agent).

\section{$\underline{\text { Polychlorinated Biphenyl (PCB) }}$}

Electrical capacitors were the only potential source of PCB contamination of this waste stream identified during the Acceptable Knowledge investigation. In 1981, the Savannah River Site PCB Committee identified several capacitors containing PCBs inside the FB-Line facility ${ }^{91}$. Extensive efforts were undertaken during the early to mid 1980s to replace or retro-fill electrical equipment containing PCB material ${ }^{92}$. Although the precise history of the six FB-Line capacitors is unknown, the annual PCB Inventory Change Report ${ }^{93}$ for calendar year 1984 stated 
that no Large Capacitors were in service at the Savannah River Site. Therefore, by the end of 1984, the potential for PCB contamination of transuranic waste from the FB-Line no longer existed. Since this waste stream was generated after January 25, 1990, there is no potential for PCB contamination.

Formaldehyde and (trans)-1,2-Dichloroethylene

On July 20, 2001 the DOE Carlsbad Field Office issued notice of a Class 2 Hazardous Waste Facility Modification for the WIPP that requires analysis of (trans)-1,2-Dichloroethylene and Formaldehyde ${ }^{114}$. This notice allowed provision for sites to preclude headspace gas analysis for waste sampled between July 13, 2001 and January 9, 2001 "as long as acceptable knowledge indicates that these compounds are not present in the waste streams being characterized". It is anticipated that waste from these streams may be headspace gas sampled during this time period. For this reason, the AK investigation specifically investigated as to whether either of these compounds could be expected in the waste. A review of the source documentation (Section 8.2) found no mention of use of either compound in the FB-Line process. This finding was supported by cognizant FB-Line technical personnel ${ }^{115}$. Additionally, MSDS sheets for various chemicals used in support of the FB-Line were reviewed. Neither compound was identified. Based on the information from FB-Line technical personnel and document reviews, neither compound is expected in the waste.

\subsection{Waste Packaging}

\section{Drum Liner}

All waste in these streams is packaged in a 90 mil (thickness) high-density polyethylene drum liner with a lid providing a tight snap fit. All liner lids are either vented using the same stainless steel filter vent as used for drums (see below) or with a minimum 0.3 inch diameter through hole. The stainless steel filter vent was used on all liners (in these waste streams) closed prior to August 19, 1997. After this date, waste generators had the option to vent drum liners using a simple 0.3 inch (or greater) hole open to the interior of the drum or to vent the liner through a filter vent. Drum liners were procured in accordance with Savannah River Site procurement specification ${ }^{79}$ NMPWMG-910067 (prior to December 19, 1991) and specification ${ }^{80-81}$ M-SPS-G-00003 thereafter.

\section{Drum}

Liners are contained in 55-gallon drums fabricated from 16 gauge (0.0598-inch nominal thickness) low carbon steel with a fully removable head. Drum finish (inside and out) is either galvanized, or two coats of high bake phenolic epoxy coating. All drums were designed, fabricated, inspected, tested, accepted as Department of Transportation Shipping Container Specification 17-C in accordance with Savannah River Site procurement specification NMP-WMG-910067 (prior to December 19, 1991) and specification ${ }^{82-86}$ M-SPS-G-00002 thereafter. 


\section{Filter Vents}

All transuranic waste drums and liners in this stream are vented through a low density porous carbon/carbon composite filter media housed in a threaded cylindrical 304 stainless steel housing. Filter Vents were procured in accordance with Savannah River Site procurement specification NMP-WMG-910067 (prior to December 19, 1991) and specification ${ }^{87-90}$ M-SPS-G-00004 thereafter.

\subsubsection{Layers of Confinement}

These waste streams are assigned four (4) layers of confinement ${ }^{102}$. Transuranic waste generated inside glove boxes and cabinets was first bagged (with twisted and tape closure) through the enclosure bag-out port (layer 1). Another layer (layer 2) was added immediately after the waste was removed from the glove box / containment. The waste is then placed in a metal storage container lined with another plastic bag. When the waste was removed from the storage container, the liner bag was twisted and tape closed (layer 3). The waste parcel was then placed in a 90-mil drum liner that was lined with a plastic bag. Prior to securing the drum liner lid, the drum liner plastic bag was twisted and taped closed (layer 4).

\subsection{Applicable EPA Waste Codes}

SR-W026-221F-HET-A: This stream is assigned hazardous waste number D008 for lead material.

SR-W026-221F-HET-B: This stream is assigned hazardous waste number D007 for chromium.

SR-W026-221F-HET-C: This stream is assigned hazardous waste number D009 for mercury.

SR-W026-221F-HET-D: This stream is assigned hazardous waste number D006 and D008 for cadmium and lead. 


\subsection{Supplemental Waste Stream Information}

\subsection{Container Examination and Evaluation Program}

During the period January 1996 through September 1997 the Savannah River Site conducted an evaluation of transuranic waste previously shipped from the FB-Line to the SRS Solid Waste Storage facility. This Container Examination and Evaluation Program (CEEP) ${ }^{95}$ was conducted to identify and segregate waste drums containing transuranic isotopes in concentrations no greater than 100 nanocuries per gram (i.e., low-level waste) from actual transuranic waste (greater than 100 nanocuries per gram). The drums determined to be low-level waste (LLW) were subsequently shipped to the Savannah River Site Low-Level waste disposal facility as certified low-level waste. These drums were from the waste stream SR-T001-221F-HET. Additionally, drums from the mixed transuranic waste streams documented herein were examined.

\section{$\underline{\text { Assay Result }}$}

\begin{tabular}{|c|c|}
\hline Total Drums Assayed & 4419 \\
\hline Drums $>100 \mathrm{nCi} / \mathrm{g}$ (i.e., TRU) & 2238 \\
\hline Drums $=$ or $<100 \mathrm{nCi} / \mathrm{g}$ (i.e., LLW) & 2181 \\
\hline
\end{tabular}

\begin{tabular}{|c|c|}
\hline Total Drums $>100 \mathrm{nCi} / \mathrm{g}$ & 2238 \\
\hline TRU Drums: Waste Stream: SR-T001-221F-HET & $\sim 500$ \\
\hline Mixed TRU Drums & 1714 \\
\hline
\end{tabular}

\section{$\underline{\text { Radiography Results }}$}

Radiography of drums determined to be transuranic waste was not performed under this program and was postponed pending preparations for shipment for disposal at the WIPP. Drums determined to be low-level waste were examined via radiography to determine compliance with low-level TSDF waste acceptance criteria. Results showing the incidence of prohibited items are shown below.

\begin{tabular}{|c|c|c|c|}
\cline { 2 - 4 } \multicolumn{1}{c|}{} & $\begin{array}{c}\text { Number of } \\
\text { Drums X- } \\
\text { Rayed }\end{array}$ & $\begin{array}{c}\text { Number of Drums } \\
\text { Observed to Contain } \\
\text { Prohibited Items }\end{array}$ & $\begin{array}{c}\text { Incidence of } \\
\text { Prohibited } \\
\text { Items }\end{array}$ \\
\hline $\begin{array}{c}\text { LLW (Originally Shipped as TRU Waste } \\
\text { stream SR-T001-221F-HET }\end{array}$ & 872 & 33 & $4 \%$ \\
\hline $\begin{array}{c}\text { Mixed Waste (low-level) } \\
\text { [Originally Shipped as a Mixed TRU] }\end{array}$ & 1309 & 120 & $9 \%$ \\
\hline Total & 2181 & 153 & $6.5 \%$ \\
\hline
\end{tabular}

Note: ${ }^{a}$ This is waste shipped from the same streams described by this report. 


\section{Discussion of Results From Supplementary Information}

The results obtained from X-Ray of the low-level and mixed waste drums from FB-Line is considered representative of these mixed TRU streams for the following reasons:

- Waste was generated and packaged in the FB-Line facility from the same locations, processes and period of generation described in this report.

- The waste was processed as using the same procedures as described in this report.

From the CEEP, the incidence of prohibited items observed in transuranic waste shipped to the Savannah River

Site transuranic waste storage facility was 4 percent. The incidence of prohibited items observed in mixed transuranic waste shipped to the Savannah River Site transuranic waste storage facility was 9 percent. The prohibited items identified were unpunctured aerosol cans and containers with more than one inch of free liquid. Any prohibited items identified during characterization of the waste streams described herein will be removed prior to disposal at the WIPP.

\subsection{WIPP Disposal Program Characterization Results for Waste Stream SR-T001-221F-HET}

The Savannah River Site WIPP Disposal Program began characterization of waste stream SR-T001-221F-HET (See Section 5.3) on August 31, 2000. As of September 19, 2001, 594 containers were radiographed, 512 containers were assayed via NDA, and the headspace gas of 405 containers was analyzed. Each characterization was conducted in accordance with the WIPP Waste Analysis Plan ${ }^{2}$. Results from the characterization of this "sister" waste stream is indicative of the physical form and radiological make up of these waste stream because the waste was generated during the same time period, in the same facility/process and managed using the same waste management procedures. With the exception of the hazardous constituents present in the waste streams documented in this report, the characterization results confirmed the physical form of the waste and the radiological make up described by this acceptable knowledge report. 


\subsection{CONTAINER SPECIFIC INFORMATION}

Completed waste generator and storage facility records (i.e., "TRU Waste Data Package" 96 forms and "Radioactive Solid Waste Burial Ground Record ${ }^{97}$ ) have been compiled for the initial containers that comprise this waste stream. These documents reside in the WIPP Records Center in Building 642-E at the Savannah River Site. A separate file containing the completed forms for each drum of waste is established. Information contained in each file is traceable to its respective drum through the FSN number. The respective forms for each drum were reviewed to ensure that all information was consistent with the waste stream as defined herein. A TRU Waste Candidate List ${ }^{68}$ for reviewed containers is maintained by the Acceptable Knowledge cognizant technical function. This list is on file in the WIPP Records Center in Building 642-E at E-Area of the Savannah River Site. The listing is updated at least annually while the respective waste stream is being characterized, or more frequently as directed by the Site Project Manager. Specific information for each individual container is assembled from this report and from characterization validation results obtained when the respective drums undergo, assay, radiography, headspace gas sampling, and visual examination (as applicable).

\subsection{ATTACHMENTS}

ATTACHMENT 1: MAPS -- 4 SHEETS

ATTACHMENT 2: REFERENCES

ATTACHMENT 3: GLOSSARY 


\title{
8.1 $\quad \underline{\text { ATTACHMENT } 1}$
}

\author{
MAPS \\ SHEET 1 ------ SAVANNAH RIVER SITE (SRS) GEOGRAPHIC LOCATION \\ SHEET 2 ------ SAVANNAH RIVER SITE (SRS) INTER-AREA MAP \\ SHEET 3 ------ SAVANNAH RIVER SITE (SRS) INTRA-AREA (F-AREA) MAP \\ SHEET 4 ------ SAVANNAH RIVER SITE (SRS) INTRA-AREA (E-AREA) MAP
}


Attachment 1; Sheet 1 of 4.

SAVANNAH RIVER SITE (SRS) GEOGRAPHIC LOCATION

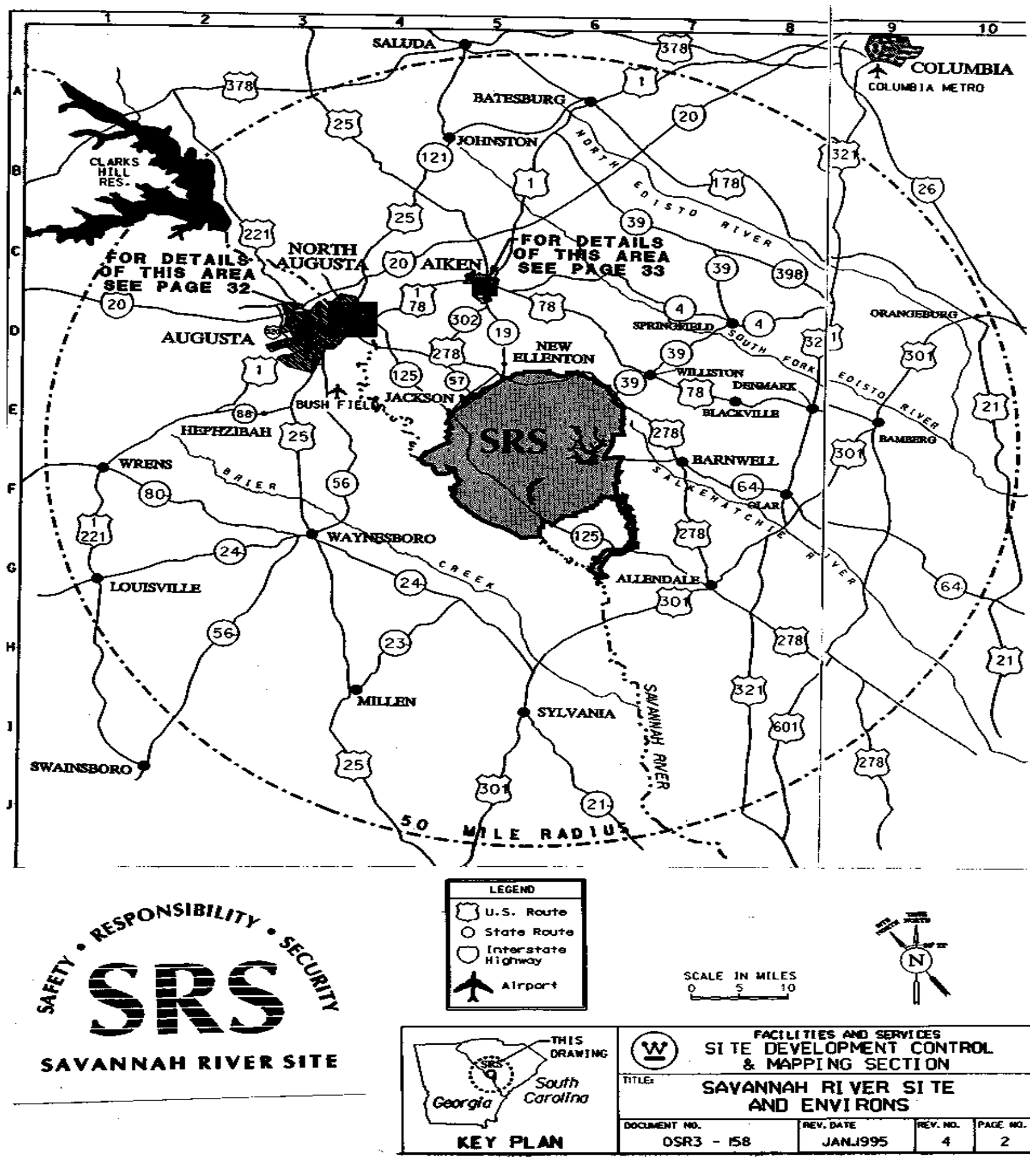


Attachment 1; Sheet 2 of 4.

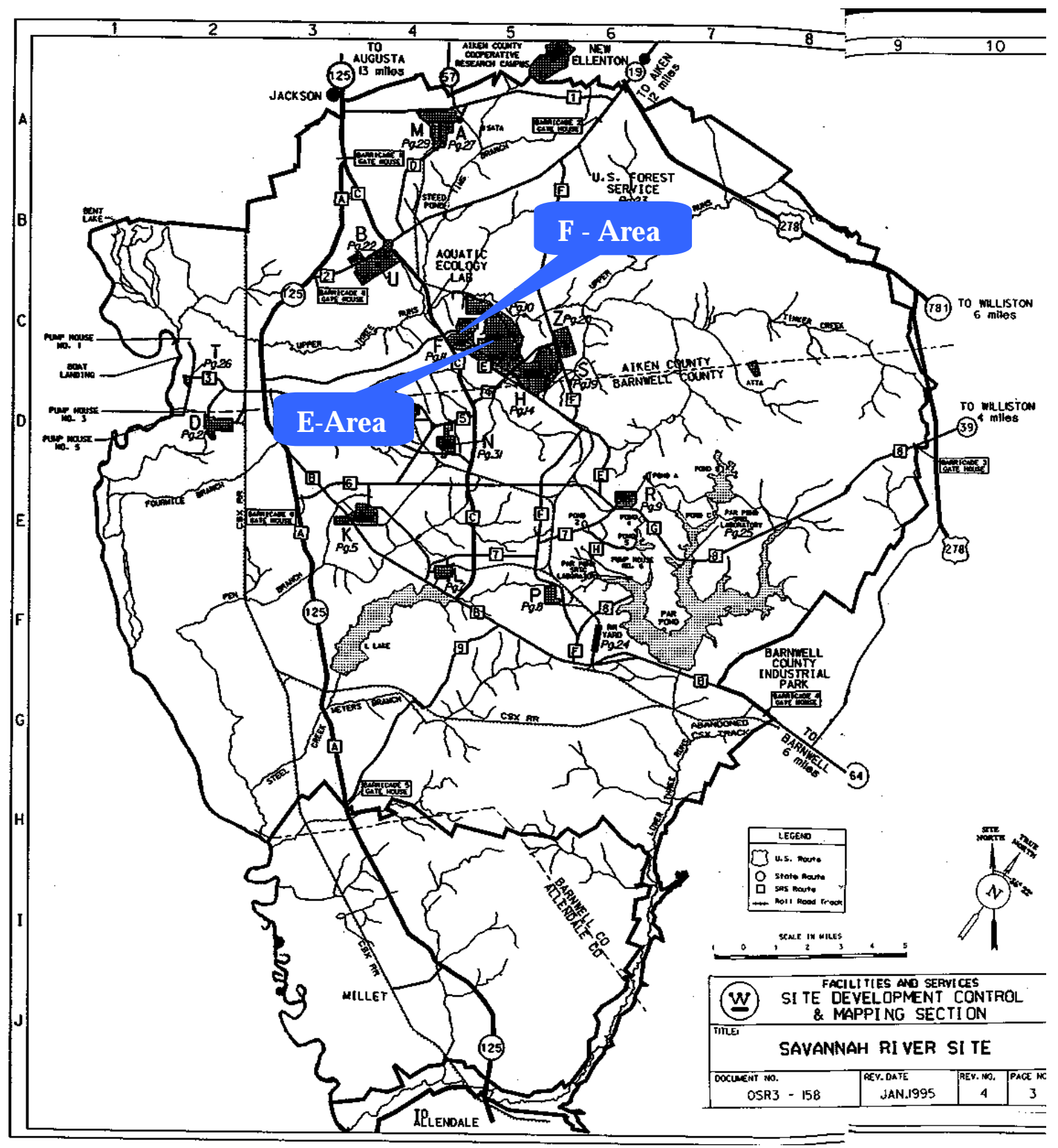


Attachment 1; Sheet 3 of 4.

\section{SAVANNAH RIVER SITE (SRS) INTRA-AREA (F-Area) MAP}

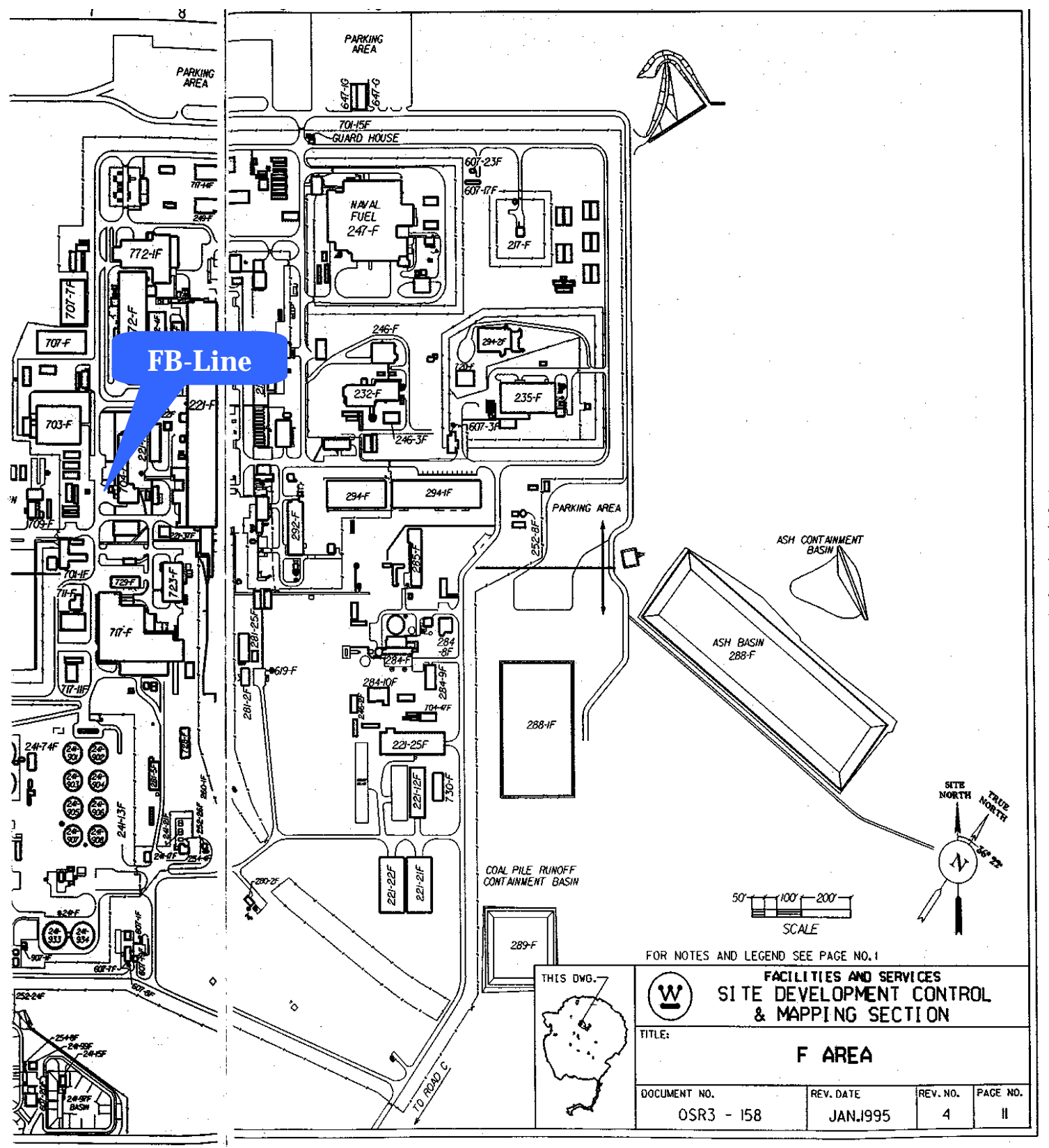


Attachment 1; Sheet 4 of 4.

SAVANNAH RIVER SITE (SRS) INTRA-AREA (E-Area) MAP

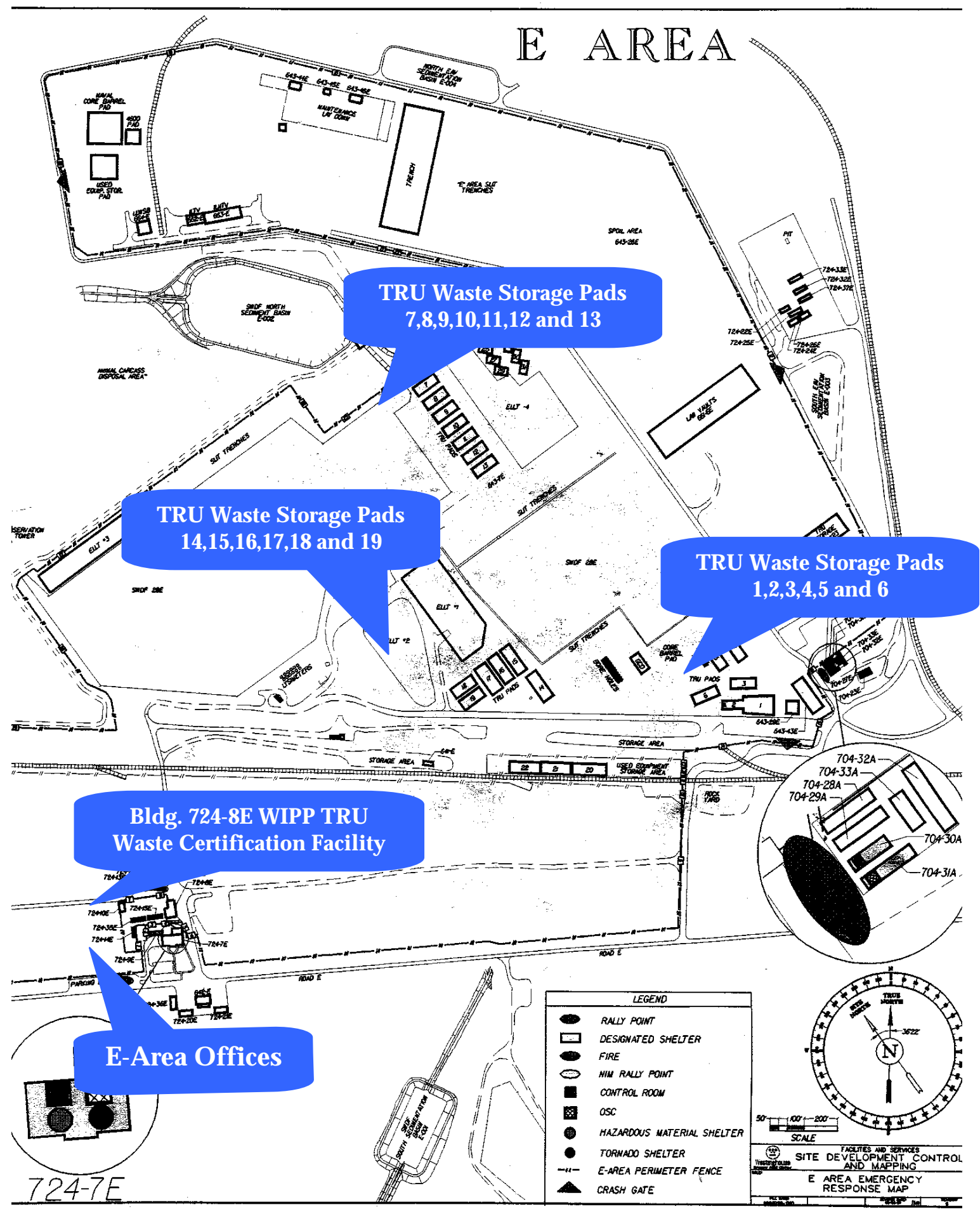




\section{REFERENCES}

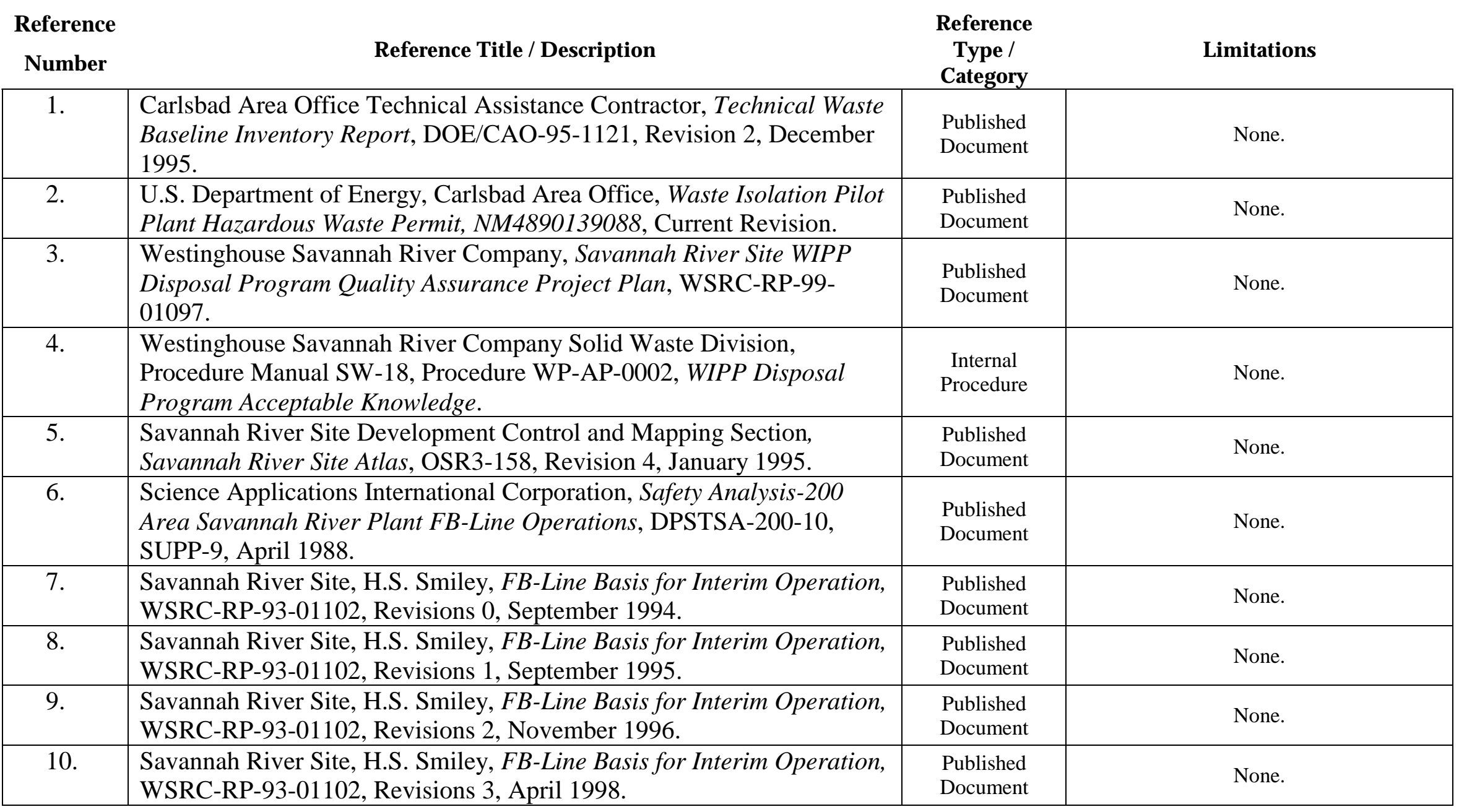




\begin{tabular}{|c|c|c|c|}
\hline $\begin{array}{c}\text { Reference } \\
\text { Number }\end{array}$ & Reference Title / Description & $\begin{array}{l}\text { Reference } \\
\text { Type / } \\
\text { Category }\end{array}$ & Limitations \\
\hline 11. & $\begin{array}{l}\text { Savannah River Site Separations Department, Packaging General and } \\
\text { Cabinet Waste Into Red Pails, DPSOL 221-FB-2502-NS, Revision 4, } \\
\text { August } 1989 .\end{array}$ & $\begin{array}{l}\text { Internal } \\
\text { Procedure }\end{array}$ & None. \\
\hline 12. & $\begin{array}{l}\text { Savannah River Site Separations Department, Packaging General and } \\
\text { Cabinet Waste Into Red Pails, DPSOL 221-FB-2502-A-NS, Revision 0, } \\
\text { March 26, } 1992 .\end{array}$ & $\begin{array}{l}\text { Internal } \\
\text { Procedure }\end{array}$ & None. \\
\hline 14. & $\begin{array}{l}\text { Savannah River Site Separations Department, Packaging General and } \\
\text { Cabinet Waste Into Red Pails, DPSOL 221-FB-2502-A-NS, Revision 2, } \\
\text { January 7, } 1993 .\end{array}$ & $\begin{array}{l}\text { Internal } \\
\text { Procedure }\end{array}$ & None. \\
\hline 15. & $\begin{array}{l}\text { Savannah River Site Separations Department, Packaging General and } \\
\text { Cabinet Waste Into Red Pails, DPSOL 221-FB-2502-A-NS, Revision 3, } \\
\text { March 9, } 1993 .\end{array}$ & $\begin{array}{l}\text { Internal } \\
\text { Procedure }\end{array}$ & None. \\
\hline 17. & $\begin{array}{l}\text { Savannah River Site Separations Department, Packaging General and } \\
\text { Cabinet Waste Into Red Pails, DPSOL 221-FB-2502-A-NS, Revision 5, } \\
\text { April 8, } 1994 .\end{array}$ & $\begin{array}{l}\text { Internal } \\
\text { Procedure }\end{array}$ & None. \\
\hline 18. & $\begin{array}{l}\text { Savannah River Site Separations Department, Packaging General and } \\
\text { Cabinet Waste Into Red Pails, DPSOL 221-FB-2502-A-NS, Revision 6, } \\
\text { September 20, } 1994 .\end{array}$ & $\begin{array}{l}\text { Internal } \\
\text { Procedure }\end{array}$ & None. \\
\hline 19. & $\begin{array}{l}\text { Savannah River Site Separations Department, Packaging General and } \\
\text { Cabinet Waste Into Red Pails, DPSOL 221-FB-2502-A-NS, Revision } 7 \text {, } \\
\text { December } 8,1994 .\end{array}$ & $\begin{array}{l}\text { Internal } \\
\text { Procedure }\end{array}$ & None. \\
\hline 20. & $\begin{array}{l}\text { Savannah River Site Separations Department, Packaging General and } \\
\text { Cabinet Waste Into Red Pails, DPSOL 221-FB-2502-A-NS, Revision 8, } \\
\text { February } 14,1997 .\end{array}$ & $\begin{array}{l}\text { Internal } \\
\text { Procedure }\end{array}$ & None. \\
\hline
\end{tabular}




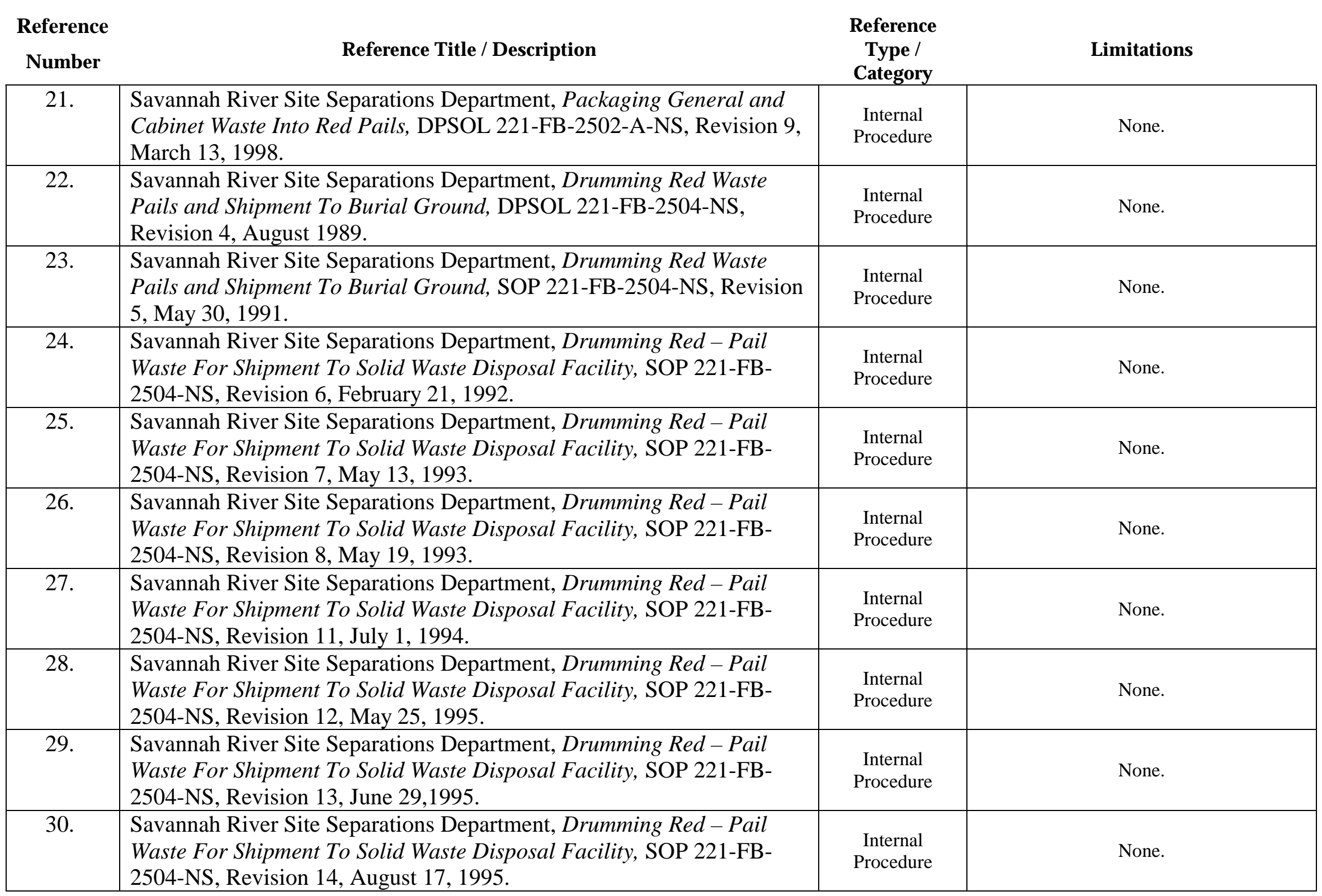




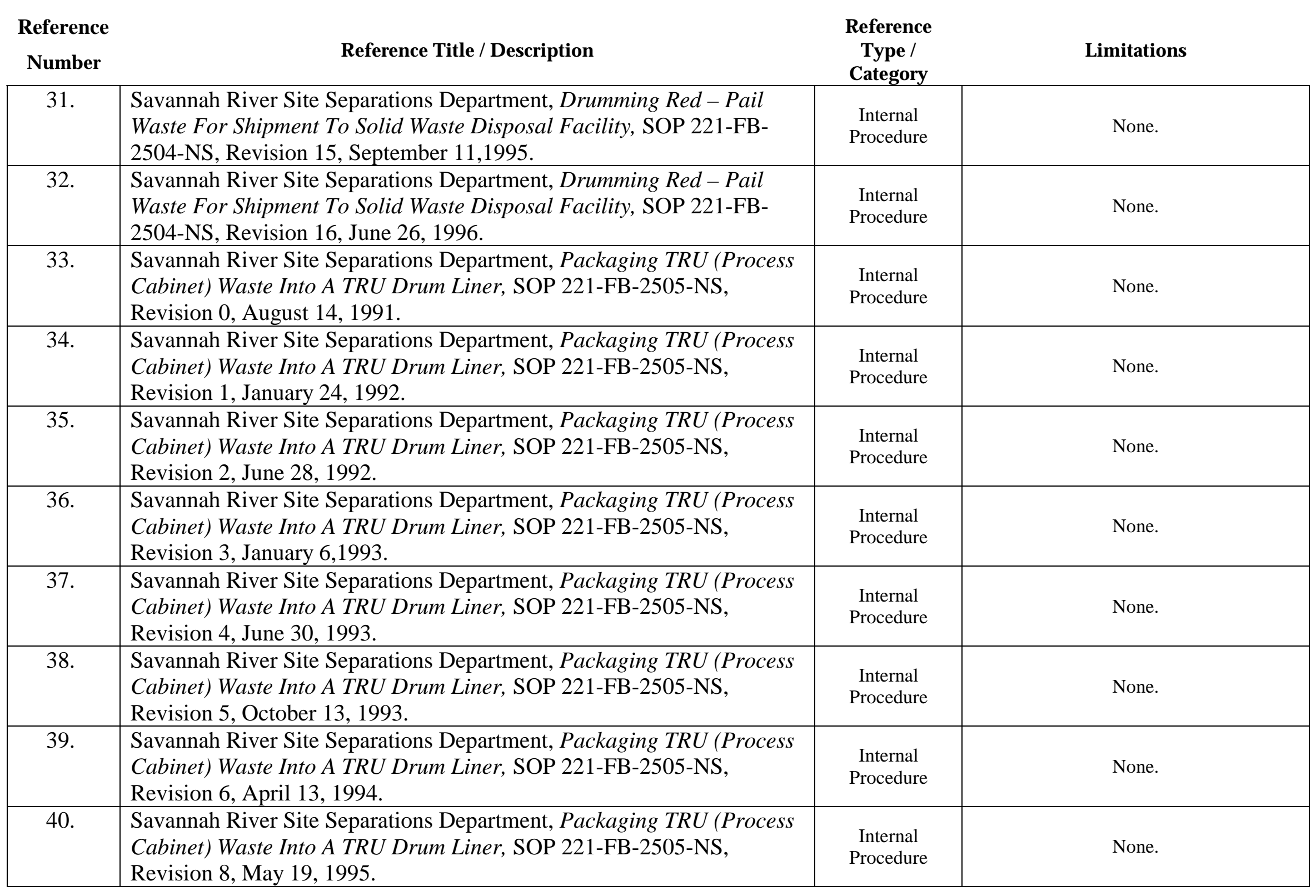




\begin{tabular}{|c|c|c|c|}
\hline $\begin{array}{c}\text { Reference } \\
\text { Number }\end{array}$ & Reference Title / Description & $\begin{array}{c}\text { Reference } \\
\text { Type / } \\
\text { Category }\end{array}$ & Limitations \\
\hline 41. & $\begin{array}{l}\text { Savannah River Site Separations Department, Packaging TRU (Process } \\
\text { Cabinet) Waste Into A TRU Drum Liner, SOP 221-FB-2505-NS, } \\
\text { Revision 9, August 23, } 1995 .\end{array}$ & $\begin{array}{l}\text { Internal } \\
\text { Procedure }\end{array}$ & None. \\
\hline 42. & $\begin{array}{l}\text { Savannah River Site Separations Department, Packaging TRU (Process } \\
\text { Cabinet) Waste Into A TRU Drum Liner, SOP 221-FB-2505-NS, } \\
\text { Revision 10, August 26, } 1995 .\end{array}$ & $\begin{array}{l}\text { Internal } \\
\text { Procedure }\end{array}$ & None. \\
\hline 44. & $\begin{array}{l}\text { Savannah River Site Separations Department, Packaging TRU (Process } \\
\text { Cabinet) Waste Into A TRU Drum Liner, SOP 221-FB-2505-NS, } \\
\text { Revision 12, September 9, } 1996 .\end{array}$ & $\begin{array}{l}\text { Internal } \\
\text { Procedure }\end{array}$ & None. \\
\hline 45. & $\begin{array}{l}\text { Savannah River Site Separations Department, Packaging TRU (Process } \\
\text { Cabinet) Waste Into A TRU Drum Liner, SOP 221-FB-2505-NS, } \\
\text { Revision 13, October 22, } 1996 .\end{array}$ & $\begin{array}{l}\text { Internal } \\
\text { Procedure }\end{array}$ & None. \\
\hline 47. & $\begin{array}{l}\text { Savannah River Site Separations Department, Packaging TRU (Process } \\
\text { Cabinet) Waste Into A TRU Drum Liner, SOP 221-FB-2505-NS, } \\
\text { Revision 15, March 13,1998. }\end{array}$ & $\begin{array}{l}\text { Internal } \\
\text { Procedure }\end{array}$ & None. \\
\hline 48. & $\begin{array}{l}\text { Savannah River Site Separations Department, Packaging TRU } \\
\text { (Excluding Process Cabinet Waste) Into A TRU Drum Liner, DPSOL } \\
\text { 221-FB-2506-NS, Revision 5, September } 1989 .\end{array}$ & $\begin{array}{l}\text { Internal } \\
\text { Procedure }\end{array}$ & None. \\
\hline 49. & $\begin{array}{l}\text { Savannah River Site Separations Department, Packaging TRU } \\
\text { (Excluding Process Cabinet Waste) Into A TRU Drum Liner, SOP 221- } \\
\text { FB-2506-NS, Revision } 6 .\end{array}$ & $\begin{array}{l}\text { Internal } \\
\text { Procedure }\end{array}$ & None. \\
\hline 50. & $\begin{array}{l}\text { Savannah River Site Separations Department, Packaging TRU } \\
\text { (Excluding Process Cabinet Waste) Into A TRU Drum Liner, SOP 221- } \\
\text { FB-2506-NS, Revision 7, July 24, } 1991 .\end{array}$ & $\begin{array}{l}\text { Internal } \\
\text { Procedure }\end{array}$ & None. \\
\hline
\end{tabular}




\begin{tabular}{|c|c|c|c|}
\hline $\begin{array}{l}\text { Reference } \\
\text { Number }\end{array}$ & Reference Title / Description & $\begin{array}{l}\text { Reference } \\
\text { Type / } \\
\text { Category }\end{array}$ & Limitations \\
\hline 51. & $\begin{array}{l}\text { Savannah River Site Separations Department, Packaging TRU } \\
\text { (Excluding Process Cabinet Waste) Into A TRU Drum Liner, SOP 221- } \\
\text { FB-2506-NS, Revision 8, April 30, } 1992 .\end{array}$ & $\begin{array}{l}\text { Internal } \\
\text { Procedure }\end{array}$ & None. \\
\hline 52. & $\begin{array}{l}\text { Savannah River Site Separations Department, Packaging TRU Hut } \\
\text { Waste (Excluding Process Cabinet Waste) Into A TRU Drum Liner, SOP } \\
\text { 221-FB-2506-NS, Revision 9, July 24, } 1992 .\end{array}$ & $\begin{array}{l}\text { Internal } \\
\text { Procedure }\end{array}$ & None. \\
\hline 54. & $\begin{array}{l}\text { Savannah River Site Separations Department, Packaging TRU Hut } \\
\text { Waste (Excluding Process Cabinet Waste) Into A TRU Drum Liner, SOP } \\
\text { 221-FB-2506-NS, Revision 11, April 13, } 1994 .\end{array}$ & $\begin{array}{l}\text { Internal } \\
\text { Procedure }\end{array}$ & None. \\
\hline 55. & $\begin{array}{l}\text { Savannah River Site Separations Department, Packaging TRU Hut } \\
\text { Waste (Excluding Process Cabinet Waste) Into A TRU Drum Liner, SOP } \\
\text { 221-FB-2506-NS, Revision 12, May 27, } 1994 .\end{array}$ & $\begin{array}{l}\text { Internal } \\
\text { Procedure }\end{array}$ & None. \\
\hline 57. & $\begin{array}{l}\text { Savannah River Site Separations Department, Packaging TRU Hut } \\
\text { Waste (Excluding Process Cabinet Waste) and TRU Decontamination } \\
\text { Waste Into A TRU Drum Liner, SOP 221-FB-2506-NS, Revision 14, } \\
\text { January 27, } 1995 .\end{array}$ & $\begin{array}{l}\text { Internal } \\
\text { Procedure }\end{array}$ & None. \\
\hline 58. & $\begin{array}{l}\text { Savannah River Site Separations Department, Packaging TRU Hut } \\
\text { Waste (Excluding Process Cabinet Waste) and TRU Decontamination } \\
\text { Waste Into A TRU Drum Liner, SOP 221-FB-2506-NS, Revision 15, } \\
\text { May 27, } 1995 .\end{array}$ & $\begin{array}{l}\text { Internal } \\
\text { Procedure }\end{array}$ & None. \\
\hline 59. & $\begin{array}{l}\text { Savannah River Site Separations Department, Packaging TRU Hut } \\
\text { Waste (Excluding Process Cabinet Waste) and TRU Decontamination } \\
\text { Waste Into A TRU Drum Liner, SOP 221-FB-2506-NS, Revision 16, } \\
\text { July 13, } 1995 .\end{array}$ & $\begin{array}{l}\text { Internal } \\
\text { Procedure }\end{array}$ & None. \\
\hline
\end{tabular}




\begin{tabular}{|c|c|c|c|}
\hline $\begin{array}{l}\text { Reference } \\
\text { Number }\end{array}$ & Reference Title / Description & $\begin{array}{c}\text { Reference } \\
\text { Type / } \\
\text { Category }\end{array}$ & Limitations \\
\hline 60. & $\begin{array}{l}\text { Savannah River Site Separations Department, Packaging TRU Hut } \\
\text { Waste (Excluding Process Cabinet Waste) and TRU Decontamination } \\
\text { Waste Into A TRU Drum Liner, SOP 221-FB-2506-NS, Revision 17, } \\
\text { May 17, } 1996 .\end{array}$ & $\begin{array}{l}\text { Internal } \\
\text { Procedure }\end{array}$ & None. \\
\hline 61. & $\begin{array}{l}\text { Savannah River Site Separations Department, Packaging TRU Hut } \\
\text { Waste (Excluding Process Cabinet Waste) and TRU Decontamination } \\
\text { Waste Into A TRU Drum Liner, SOP 221-FB-2506-NS, Revision 18, } \\
\text { June 6, } 1996 .\end{array}$ & $\begin{array}{l}\text { Internal } \\
\text { Procedure }\end{array}$ & None. \\
\hline 62. & $\begin{array}{l}\text { Savannah River Site Separations Department, Packaging TRU Hut } \\
\text { Waste (Excluding Process Cabinet Waste) and TRU Decontamination } \\
\text { Waste Into A TRU Drum Liner, SOP 221-FB-2506-NS, Revision 19, } \\
\text { December 12, } 1996 .\end{array}$ & $\begin{array}{l}\text { Internal } \\
\text { Procedure }\end{array}$ & None. \\
\hline 63. & $\begin{array}{l}\text { Savannah River Site Separations Department, Packaging TRU Hut } \\
\text { Waste (Excluding Process Cabinet Waste) and TRU Decontamination } \\
\text { Waste Into A TRU Drum Liner, SOP 221-FB-2506-NS, Revision 20, } \\
\text { October 31, } 1997 .\end{array}$ & $\begin{array}{l}\text { Internal } \\
\text { Procedure }\end{array}$ & None. \\
\hline 65. & $\begin{array}{l}\text { Savannah River Site Solid Waste Division, Savannah River Site Waste } \\
\text { Acceptance Criteria Manual-1S, E-Area TRU Pads-Transuranic Waste } \\
\text { Acceptance Criteria, WAC 3.06. }\end{array}$ & $\begin{array}{l}\text { Published } \\
\text { Document }\end{array}$ & None. \\
\hline 66. & $\begin{array}{l}\text { U.S. Department of Energy, Carlsbad Area Office, Waste Acceptance } \\
\text { Criteria for the Waste Isolation Pilot Plant, DOE/WIPP-069, Revision } \\
\text { Current }\end{array}$ & $\begin{array}{l}\text { Published } \\
\text { Document }\end{array}$ & None. \\
\hline 67. & This Reference Number Not Used & N/A & N/A \\
\hline 68. & $\begin{array}{l}\text { G.F. Lunsford to J.A. D'Amelio, et al., Inter-Office Memorandum, } \\
\text { Candidate Container Listing for Waste Streams "SR-W026-221F-HET- } \\
\text { A through D", SWE-STW-2001-00100, Latest Revision. }\end{array}$ & $\begin{array}{c}\text { Unpublished } \\
\text { Data }\end{array}$ & None. \\
\hline
\end{tabular}




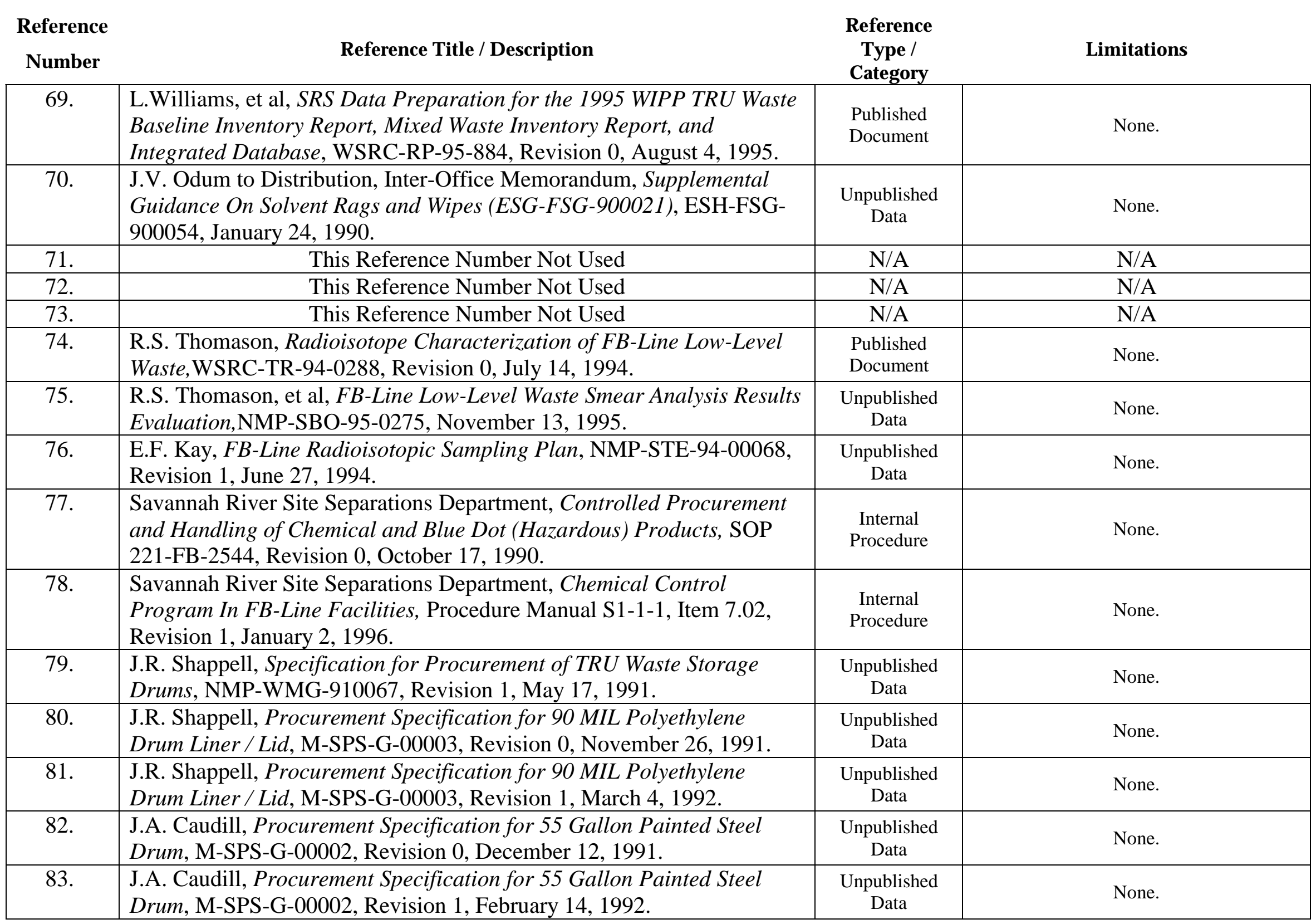




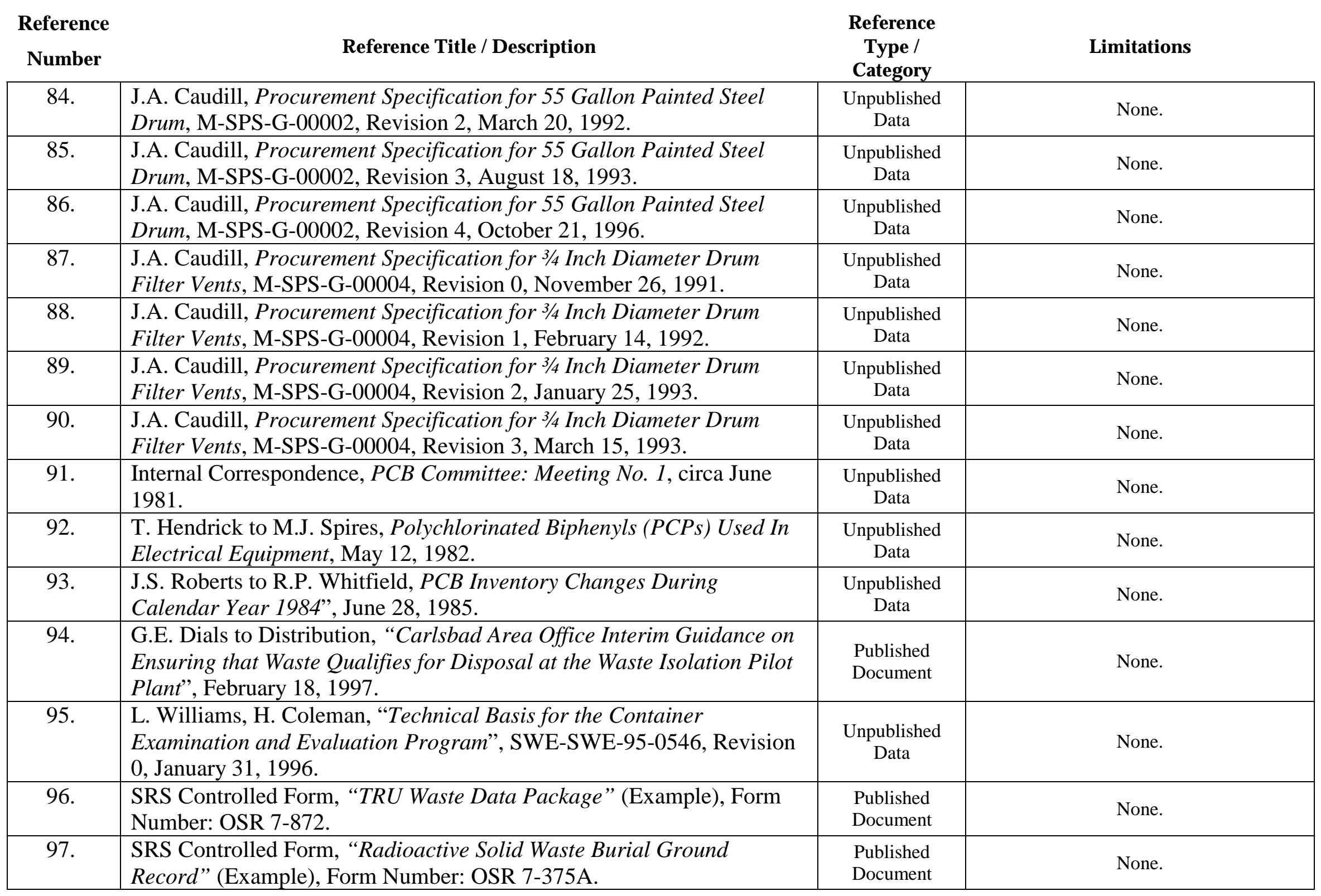




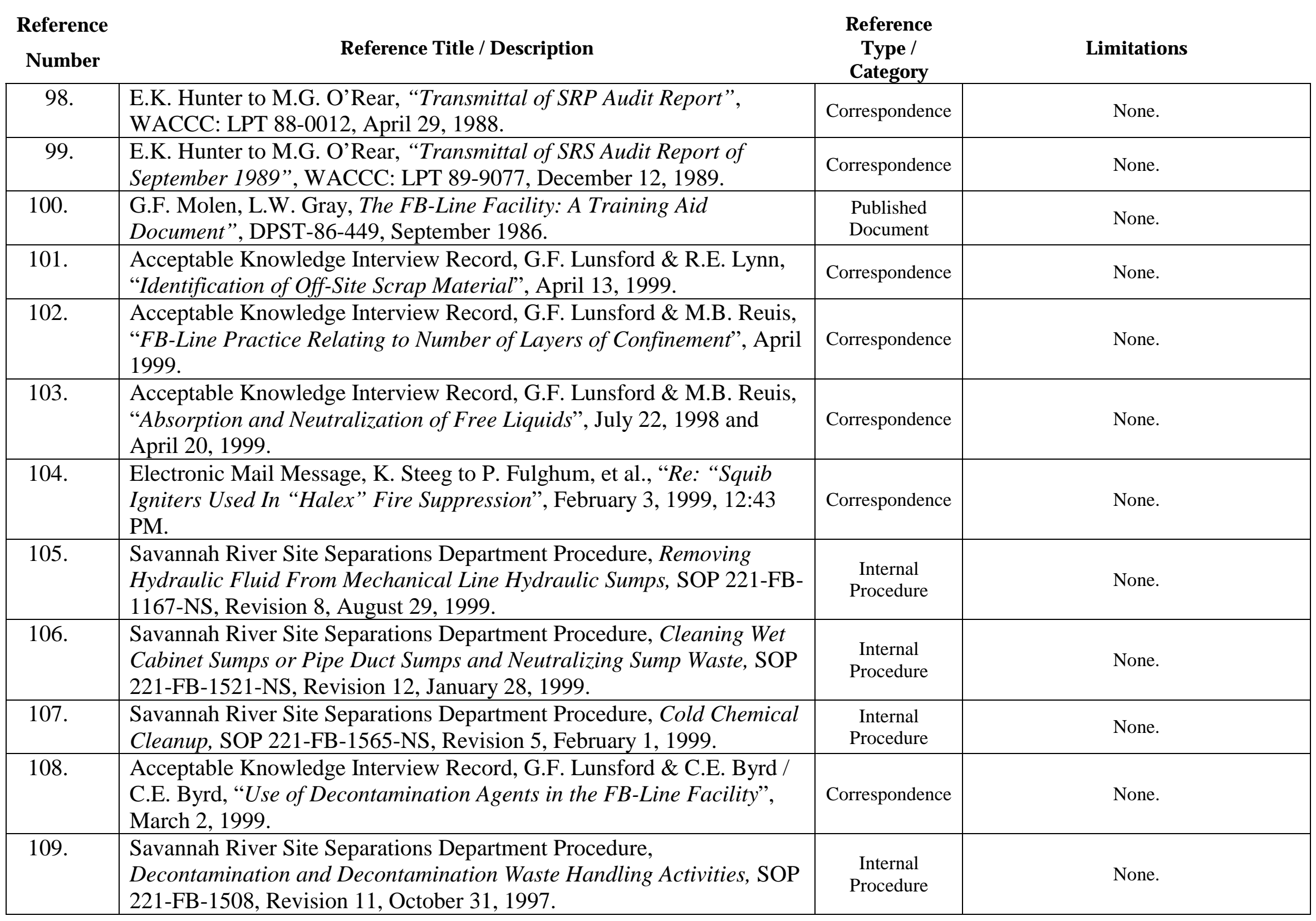




\begin{tabular}{|c|c|c|c|}
\hline $\begin{array}{c}\text { Reference } \\
\text { Number }\end{array}$ & Reference Title / Description & $\begin{array}{l}\text { Reference } \\
\text { Type / } \\
\text { Category }\end{array}$ & Limitations \\
\hline 110. & $\begin{array}{l}\text { R.S. Thomason to J.S. Bellamy; Impact of Proposed Change in } \\
\text { Plutonium Isotopics on FB-Line Low-Level Waste Radioisotopic } \\
\text { Characterization, NMS-ESS-96-0014, May 30, } 1996 .\end{array}$ & Correspondence & None. \\
\hline 111. & $\begin{array}{l}\text { N.S. Dienes to W.H. James et al.; Specifications for Plutonium Shipped } \\
\text { to the Rocky Flats Plant, United States Government Memorandum, circa } \\
\text { 1985. }\end{array}$ & Correspondence & None. \\
\hline 113. & This Reference Number Not Used & N/A & N/A \\
\hline 114. & $\begin{array}{l}\text { DOE-CBFO to Distribution, Implementation of the Class } 2 \text { Hazardous } \\
\text { Waste Facility Permit Modification Requiring Analysis of (trans)-1,2- } \\
\text { Dichloroethylene and Formaldehyde, July 20, } 2001 .\end{array}$ & Correspondence & None. \\
\hline 115. & $\begin{array}{l}\text { Telecon Record, G.F. Lunsford with J.W. McClard, Question } \\
\text { Concerning Existence of (trans)-1,2-Dichloroethylene or Formaldehyde } \\
\text { in FB-Line TRU Waste, September 19, } 2001 .\end{array}$ & Correspondence & None. \\
\hline
\end{tabular}




\subsection{ATTACHMENT 3}

\section{GLOSSARY}

RED PAIL: A metal five gallon can with a crimp fit lid used to temporarily contain transuranic waste cuts prior to placement into a waste drum liner / drum. Pails used for transuranic waste are painted red for identification as transuranic waste. Figure 12 depicts a typical "red pail".

WASTE "CUT": An individual parcel of waste packaged in a plastic bag. Each cut is managed as a discrete waste entity prior to placement into a waste drum liner / drum. Figure 13 depicts an example of a waste cut.

$$
\begin{gathered}
\text { Waste Inside } \\
\text { Plastic Bag }
\end{gathered}
$$

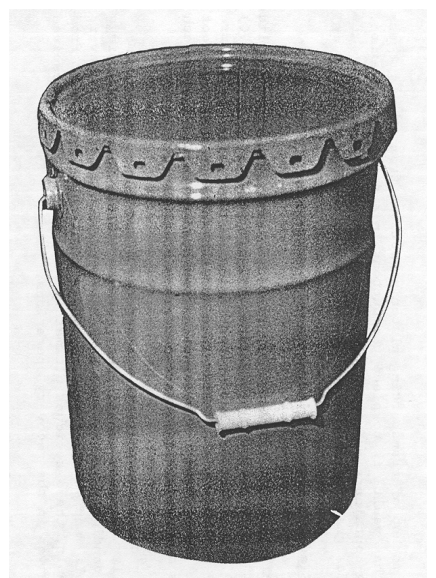

Figure 12- Typical Five Gallon Red Pail

Tape Closure

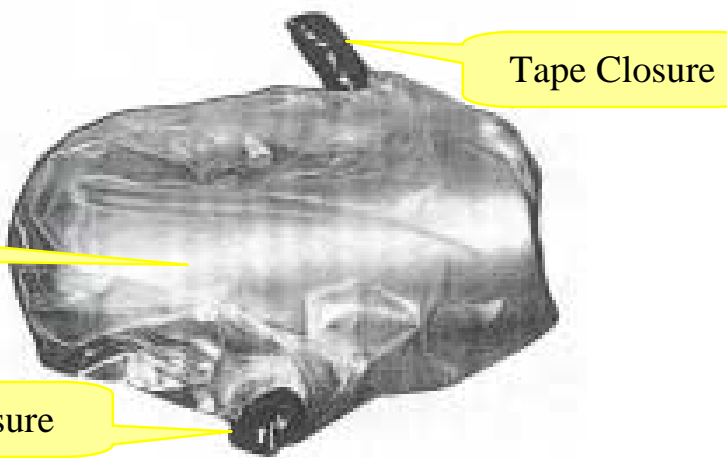

$\underline{\text { Figure 13- Example Waste Cut }}$

SWEEPINGS: Plutonium bearing residue which falls or spills to the floor of glove boxes or cabinets and is collected by sweeping or vacuum and deposited into storage containers for later recycle/recovery. 